\title{
Differential water-use strategies in co-occurring pioneers and late-successional tree species in secondary tropical montane forests of Eastern Himalaya
}

Manish Kumar ( $\sim$ manish-kumar@cgiar.org )

International Water Management Institute https://orcid.org/0000-0002-6780-9336

Yangchenla Bhutia

Ashoka Trust for Research in Ecology and the Environment

Gladwin Joseph

Conservation Biology Institute

Jagdish Krishnaswamy

Indian Institute for Human Settlements

\section{Research Article}

Keywords: Sap flow, Transpiration, Tree Ecophysiology, Plant Water relations, Secondary Forests, Ecohydrology

Posted Date: January 28th, 2022

DOI: https://doi.org/10.21203/rs.3.rs-1283903/v1

License: (c) (i) This work is licensed under a Creative Commons Attribution 4.0 International License.

Read Full License 


\section{Cover Letter to the Editor}

4 Dear Editor,

We are pleased to submit an original research article entitled "Differential water-use strategies in cooccurring pioneers and late-successional tree species in secondary tropical montane forests of

8 Eastern Himalaya" for consideration for publication in the journal Trees.

The manuscript focuses on the plant-water relations in hitherto unstudied tropical montane forests (TMFs) of Eastern Himalaya, one of the 30 global biodiversity hotspots and global 200 ecoregions of

11 importance. In this manuscript, using sap flow probes and the soil-plant-atmosphere-continuum (SPAC)

12 framework, we present first detailed insights into the drivers of the variability in plant-water relations of

13 cooccurring pioneers and late-successional species in a secondary Eastern Himalayan TMF. We

14 hypothesized that the plant-water use by the pioneer species will be high but equally likely to be affected

15 by environmental extremes, whereas late-successional species will have relatively stable water-use patterns.

16 Our study site is the wettest (mean annual precipitation $=4500 \mathbf{~ m m ~} \mathbf{~ r r}^{-1}$ ) high-elevation $(>2000$

17 meters) site in the world, where direct sap flow measurements have been carried out so far. Thus, we

18 also predicted that, due to high moisture availability, the ecosystem productivity is likely to be energy

19 limited. We report one of the highest daily stand transpirations $(5.3 \mathrm{~mm})$ from among tropical montane or

20 lowland forests, along with significant nocturnal transpiration, which is seen as an adaption to the

21 dominantly afternoon-late-night summer rainfall in Eastern Himalaya. The drivers of transpiration shifted

22 from energy (sunlight) in winters to atmospheric moisture availability (Vapour pressure deficit) in

23 summers, whereas the differential access to solar radiation, a characteristic of the forest canopy in

24 secondary forests, induced significant radial and azimuthal variability in sap flow. We postulate that the

25 shallow-rooted pioneers are more responsive to environmental extremes and soil moisture fluctuations than

26 the deep-rooted late-successional species. Thus, these regenerating secondary TMFs are highly susceptible

27 to the negative impacts of the predicted warming and decline in winter precipitation.

28 We truly believe Trees will be an outstanding forum to share our work as the work provides first mechanistic insights into the tree ecophysiological processes driving plant-water use and tree30 environment interactions among different functional groups from the Eastern Himalaya. The study

31 will contribute to the scarce literature on plant-water relations from TMFs globally, and Himalaya

32 particularly, and thus will be of great interest to many readers of your journal. More importantly, being the 33 first report from the Eastern Himalaya, the study will interest the general public, media, policymakers, and 34 governments in highlighting the vulnerabilities of regenerating secondary forests to climate change 35 impacts. 
36 The submitted manuscript entails original work and has not been published or submitted anywhere 37 else. We do not have any conflicts of interest to disclose.

38

39 Thank you for your consideration of this manuscript.

40 Dr. Manish Kumar

41 (Corresponding author, On behalf of all authors)

42 International Water Management Institute, Delhi, India

43 Email id: manish-kumar@cgiar.org, Phone Number: +91 9800284722

44 
45 Differential water-use strategies in co-occurring pioneers and late-successional tree species in 46 secondary tropical montane forests of Eastern Himalaya

47 Authors: Manish Kumar ${ }^{\mathrm{a}^{*}}$, Yangchenla Bhutia ${ }^{\mathrm{b}, \mathrm{c}}$, Gladwin Joseph $^{\mathrm{b}, \mathrm{d}}$ and Jagdish Krishnaswamy ${ }^{\mathrm{b}, \mathrm{e}}$

48 anternational Water Management Institute, Delhi 110012, India.

$49{ }^{\mathrm{b}}$ Ashoka Trust for Research in Ecology and the Environment (ATREE), Bangalore 560064, India.

$50 \quad$ 'Sikkim State Council of Science \& Technology, Gangtok 737102, India.

$51{ }^{\mathrm{d}}$ Conservation Biology Institute, Oregon 97333, USA.

52 eSchool of Environment and Sustainability, Indian Institute for Human Settlements, Bangalore 560080, 53 India.

54 *Corresponding author: Manish Kumar

55 Corresponding authors contact information

56 Manish Kumar

57 2nd Floor, CG Block C, NASC Complex,

58 DPS Marg, Pusa, New Delhi 110012

59 Telephone: +91-11 25843536

60 Primary email id: manish-kumar@cgiar.org

61 Secondary email id: manish.ecohydro@gmail.com

62 Phone Number: +919800284722

63 


\section{Confidential manuscript submitted to Trees}

\section{Abstract}

65 Plant-water relations in secondary tropical montane forests (TMFs) are driven by complex interactions 66 between environmental conditions, species composition, and forest structure. We investigated the 67 differential water-use strategies of cooccurring pioneers and late-successional tree species in a secondary $68 \mathrm{TMF}$ of Eastern Himalaya, India. It is the wettest (mean annual precipitation $=4500 \mathrm{~mm} \mathrm{yr}^{-1}$ ) high69 elevation (> $2000 \mathrm{~m}$ ) site in the world. The observed maximum daily stand transpiration $(5.3 \mathrm{~mm})$ is 70 highest among other tropical montane or lowland forests. Although energy-limited, increased moisture 71 availability allowed the observed sap flux densities from the studied species, Symplocos racemosa, Eurya 72 acuminata, and Castanopsis racemosa, to be 3-9 times higher than their conspecifics from relatively drier

73 TMFs. Interestingly, differential access to solar radiation, a characteristic of the forest canopy in secondary 74 forests, induced significant radial and azimuthal variability in sap flow. Solar radiation was the key driver 75 of transpiration in energy-limited winters and Vapour pressure deficit in energy-abundant summers.

76 Nocturnal (1800-0500 h) transpiration was significant (13.8\%) part of daily $\mathrm{T}$ and was dominated by pre-

77 dawn flux. Shallow-rooted pioneers, S. racemosa and E. acuminata, exhibited strong midday depression in 78 sap flow in response to environmental extremes and soil moisture fluctuations, whereas the deep-rooted

79 late-successional $C$. hystrix transpired unaffected. The complex interactions between different successional 80 groups for accessing changing energy and moisture conditions are highlighted for prioritized conservation 81 and management of these secondary forests in Eastern Himalaya.

\section{Keywords}

83 Sap flow, Transpiration, Tree Ecophysiology, Plant Water relations, Secondary Forests, Ecohydrology

\section{$84 \quad$ Key message}

85 First reports of contrasting and interactive water use strategies among co-occurring pioneers and late-

86 successional tree species with highest maximum daily stand transpiration $(5.3 \mathrm{~mm})$ reported from

87 secondary tropical Eastern Himalayan forests. 


\section{Confidential manuscript submitted to Trees}

\section{Introduction}

In most terrestrial systems, the availability of energy (and light) and water are the primary drivers of water-use by vegetation (Schulze et al. 1987, Heimann and Reichstein 2008). Spatiotemporal variability in temperature, precipitation, and soil moisture exert significant controls on the distribution and composition of vegetation (Todd et al. 2010, Piedallu et al. 2013). Over the long term, vegetation adapts to the environmental conditions and biological competition through functional traits and strategies enhancing photosynthesis and water-use efficiency (Ackerly et al. 2000, Troch et al. 2009, Tang et al. 2014). In turn, vegetation also significantly alters the availability of water in their environment through transpiration and hydraulic redistribution (Neumann and Cardon 2012, Schlesinger and Jasechko 2014). Transpiration taps into subsurface moisture and releases it into the atmosphere altering local moisture balance (Federer 1973, Barros and Lang 2003). This see-saw interaction between vegetation and moisture availability is the focus of studies on the Soil-Plant-Atmosphere-Continuum (SPAC), an active area of research in the field of ecohydrology (Asbjornsen et al. 2011, Manzoni et al. 2013, Mencuccini et al. 2019). The SPAC framework is mainly focused on the process of transpiration, which is the movement of water from the soil to the atmosphere via plant, based on a gradient of total water potential. It is driven by environmental variables like Vapour Pressure Deficit (VPD), an index of atmospheric dryness, light and soil moisture availability, and ecophysiological traits controlling plant water-use (Hetherington and Woodward 2003, Asbjornsen et al. 2011, Manzoni et al. 2013). These ecophysiological traits, such as wood anatomy, rooting depth, stomatal density, sapwood density, have evolved through competition and adaptation by co-occurring species belonging to different functional groups, and are expressed as inter-specific variability (between individuals of different species) (Phillips et al. 2010, Hernandez-Santana et al. 2015). The intra-specific (within individuals of the same species) variations manifests as radial and azimuthal variability in sap flow, and are influenced by growth stages, size, and individual responses to the microclimate (Fiora and Cescatti 2006, Berdanier et al. 2016, Berry et al. 2018). Such species-based understanding is important while scaling transpiration to individual and stand-levels, which requires using appropriate scalars, including biometric scalars like sapwood area, leaf area index (LAI), basal area, and tree height (Hatton et al. 1995, Barbour et al. 2005, Mackay et al. 2010). Failure to incorporate the intra and inter-specific variability, along with logistical limitations of measuring sap flow in a limited number of tree individuals, can 


\section{Confidential manuscript submitted to Trees}

117 contribute to large biases in estimating stand transpiration, especially in bio-diverse secondary tropical

118 montane forests (TMFs) (Čermák et al. 2004, Forrester 2015, Hernandez-Santana et al. 2015). traits, and transpiration in TMFs are largely restricted to the tropical Andes and South-East Asia with very

121 little research coming from Himalaya (Bruijnzeel, Mulligan, \& Scatena, 2011; Buytaert, Celleri, Willems,

122 Bièvre, \& Wyseure, 2006; Célleri \& Feyen, 2009). Studies on plant-water relations from the Himalaya have

123 focused on inter-specific patterns in leaf water potential with environmental gradients, most coming from

124 the drier Western Himalaya (Poudyal et al., 2004; Singh et al., 2006; Zobel \& Garkoti, 2001). Direct

125 measurements of whole-tree transpiration using sap-flow methods are rare, and here Ghimire et al. (2014)

126 stand out for comparing variability in transpiration rates between needle-leaved Chir pine (Pinus

127 roxburghii) and broad-leaved Oak forests in Central Himalaya. Previous studies have highlighted the

128 crucial role of seasonal soil moisture fluctuations on phenology and growth cycles in broad-leaved trees

129 (Chand, Poudyal, \& Jha, 2017; Singh, Tewari, Singh, \& Pathak, 2000; Tewari, Bhatt, \& Mittal, 2016).

130 Similarly, research indicates differential growth rates between dry and wet sites and across elevation

131 gradients, again with soil moisture being the key limiting variable (Poudyal et al. 2004b, Shrestha et al.

132 2015). Others have explored the variability in their ecophysiological responses to seasonal moisture deficit

133 across elevation, species range and canopy structure (Zobel et al. 2001, Singh, Zobel, Garkoti, et al. 2006,

134 Tewari et al. 2018). They have also pointed that a majority of the broad-leaved TMFs in the Himalaya are

135 secondary in nature due to the long history of human forest use (Ramakrishnan and Kushwaha 2001,

136 Kanade and John 2018). Secondary TMFs differ significantly from their primary counterparts in terms of

137 species composition, stand structure, and ecophysiological functioning (Ramakrishnan and Kushwaha

138 2001, Nogueira et al. 2004). Globally secondary forests form a significant carbon sink and play a major

139 role in regional ecohydrology (Giambelluca 2002, Wohl et al. 2012, Brown et al. 2019). However, few

140 studies have explored the ecohydrological dynamics of bio-diverse secondary tropical montane forests in

141 Eastern Himalaya, where vegetation-driven evapotranspiration can range from 30\% - 47\% of the total water

142 budget (Acharya et al. 2011, Patle et al. 2020). The region is threatened by the prediction of a high rate of

143 warming $\left(+5^{\circ} \mathrm{C}\right)$ and precipitation changes ( $\left.+40 \%\right)$ under climate change (Kulkarni et al. 2013). 

topography, complex geomorphology, high rainfall, and diverse ecosystems (Bookhagen and Burbank

146 2010, Tambe et al. 2011). Broad-leaved forests (800 - 2800 masl) form the most dominant vegetation type

147 in Sikkim (Tambe et al. 2011). A third of these are secondary forests modified by decades of anthropogenic

148 pressures and remain understudied (Kanade and John 2018). They provide sanctuary to the principal water

149 resources, the springs and streams, and understanding their plant-water relations is critical to the regional

150 water and ecological security (Tambe et al. 2012). Plant-water relations have not been studied in the wet

151 secondary TMFs of Eastern Himalaya using direct whole-tree methods. To address the knowledge gap, we

152 use the SPAC framework to understand the relative influences of the wet tropical environment and

153 secondary forest structure on plant-water relations in an East-Himalayan broad-leaved evergreen secondary

154 TMF. Specifically, we address two main questions: (a) What are the environmental and ecophysiological

155 drivers of water-use in key broad-leaved evergreen tree species under wet tropical Eastern Himalayan eco-

156 climate? and (b) How the plant-water strategies differ between co-occurring pioneers and late-successional

157 species in a secondary forest structure? The study is conducted in an early successional secondary forest

158 stand which is representative of the East Himalayan broad-leaved evergreen wet montane forest

159 classification and is dominated by a mix of pioneers and late-successional emergent species. The site is

160 unique in being the wettest (mean annual precipitation (MAP) $4500 \mathrm{~mm} \mathrm{yr}^{-1}$ ) high-elevation (> 2000

161 masl) site in the world, where direct transpiration measurements have been carried out so far (McJannet et

162 al. 2007, Bruijnzeel et al. 2011). Being one of the 30 global biodiversity hotspots and global 200 ecoregions

163 of importance, the studied broad-leaved forests in Eastern Himalaya are also the most species-rich TMFs in

164 the world (Brooks et al. 2006, Bajracharya et al. 2010).

\section{Materials and methods}

\subsection{Study site and forest stand description}

169 Wildlife sanctuary (FWS), Sikkim, which is part of the Teesta River basin (Figure 1). The total watershed 170 area was 1.6 hectares and elevation ranged from 2150 - 2400 meters above sea level (masl). The mean 
171 annual precipitation between the years 2013-2016 was 4649 $\pm 120 \mathrm{~mm}$ and the mean annual daily

172 temperature ranged from $-2^{\circ} \mathrm{C}$ to $24^{\circ} \mathrm{C}$. The year is divided into three distinct seasons: Summer (MAM)

173 characterized by warm days, cloudy afternoons, significant pre-monsoon precipitation, and high

174 evapotranspiration; Monsoon (JJASO) with concentrated precipitation, high humidity, and low

175 evapotranspiration; and Winter (NDJF) with bright days, cold nights, occasional snowfall events and

176 moderate evapotranspiration (Pandey et al. 2016, Kumar et al. 2021). The forest sloped at $10^{\circ}-35^{\circ}$,

177 predominantly facing the north-east direction, and the soil was well-drained sandy-loam with an average

178 soil depth of $70 \mathrm{~cm}$. The forest stand represents the East Himalayan broad-leaved wet montane forests

179 (Sudhakar et al. 2008, Kanade and John 2018) characterized by (a) the dominance of broad-leaved

180 evergreen species and (b) sub-tropical montane climate with high precipitation and strong diurnal and

181 seasonal temperature gradients. The vegetation data were derived from five 0.1 ha (100 m X $10 \mathrm{~m})$

182 vegetation survey plots laid in FWS as part of another study (Bhutia et al. 2019). In each plot, all

183 individuals above $30 \mathrm{~cm}$ circumference at breast height were enumerated and voucher samples were

184 collected for identification. The composition and local history mark the stand as early successional

185 secondary forest regenerating from past anthropogenic pressures (Sudhakar et al. 2008, Kanade and John

186 2018). The top three dominant species in terms of tree density and basal area, Symplocos racemosa, Eurya

187 acuminata and Castanopsis hystrix, were chosen for sap flow instrumentation (see supplementary data

188 Figure S1). Out of these, the first two, S. racemosa and E. acuminata, are pioneers while the C. hystrix is a 189 late-successional species.

191 Figure 1: (a) Digital elevation model (DEM) map of Sikkim showing; (b) the elevation profile of the

192 Fambong-Lho wildlife sanctuary (FWS) and (c) delineated catchment maps of FMBL stream in FWS. The 193 maps are prepared in QGIS (QGIS.org 2021) using the ASTERGDEM 003 (elevation in meters).

195 In the forest stand, the pioneer tree species dominate the short-statured canopy. The older and large-girthed 196 remnant individuals of the Fagaceae family such as $C$. hystrix standing out as emergent. Table 1 
197 summarises the information on rooting depth, phenology, and other ecophysiological characteristics of the

198 three species collated from available literature and personal observations (Ohsawa et al. 1986, Suzuki et al.

199 1991, Sundriyal and Sharma 1996, 2003, Chettri et al. 2002, Sharma et al. 2011, Li et al. 2013).

201 Table 1. Life-forms and ecophysiological characteristics of the three species used for sap flow 202 measurements.

Sap flux was measured in a total of 13 individuals of the three dominant species using Granier's thermal dissipation method-based probes (TDPs) (Table 2) (Granier 1987, Lu et al. 2004). The sample size of 13 trees ( 5 trees each of $S$. racemosa and E. acuminata, and 3 trees of $C$. hystrix) was at the higher end of the average number of trees sampled in sap flow studies globally (Mackay et al. 2010, Asbjornsen et al. 2011). TDPs are known to perform well in cold and low-flow conditions (Lu et al. 2004, Chan and Bowling 2017). The probes were manufactured locally based on suitable modifications to the original design with only the top one cm measuring the sap flux (for details see Phillips et al. 1996, James et al. 2002, Harmon 2009, Davis et al. 2012). The choice of radial and azimuthal installation sites on a tree was carefully done to optimize number of sensors and xylem variability (Guyot et al. 2015). We installed radial probes $(1-5 \mathrm{~cm}$ in length) spirally at one $\mathrm{cm}$ incremental depth from the cambium in one tree per species. The replicate trees were fitted with two 2-cm length probes installed in north and south azimuthal aspects (Shinohara et al. 2013, Komatsu et al. 2016). The length of sapwood was measured using wood cores extracted using an increment borer. $C$. hystrix showed distinct heartwood formation and only the outer xylem $(4-5 \mathrm{~cm})$ was

218 functional. No heartwood was detected in S. racemosa and E. acuminata and the entire xylem was assumed

219 functional, a characteristic of diffuse-porous species (Berdanier et al. 2016). The probe signals (in 220 millivolts) were recorded and converted to temperature difference $\left(\Delta \mathrm{T}\right.$ in $\left.{ }^{\circ} \mathrm{C}\right)$ between the heater and 
$222 \mathrm{~cm}^{2} \mathrm{hr}^{-1}$ ) was computed using Granier's empirical equation (equation 1) and maximum temperature

223 difference $\left(\Delta \mathrm{T}_{\max }\right)$ was calculated daily (for details see Granier 1987, Lu et al. 2004).

$224 J=119 * 10^{-6} * 3600 *\left(\frac{\left(\Delta T_{\max }-\Delta T\right)}{\Delta T}\right)^{1.231}$

225 The period of data collection was from November 2013 to May 2014. The first two weeks of data were

226 ignored to avoid sap flux underestimation due to installation wounds (Wiedemann et al. 2016). Due to very

227 wet conditions, especially in the summer, it was difficult to maintain the field instrumentation for a long

228 duration and data gaps were inevitable (see supplementary data Figure S2 for time-series plots of the data

229 used in the analysis). After due quality checks, a total of 114 days of sap flow data across all species was

230 used for the final analysis (species-wise break-up provided in Table 2). The data processing, analysis, and

231 visualization were done in R (version 3.6.0) (R Core Team 2021) using RStudio (RStudio Team 2021).

Table 2. Biometric details ( \pm standard deviation) along with the total number of data days and number of 234 radial probes installed for the three species.

\subsection{Environmental and hydrological measurements}

Soil water potential was recorded at $10 \mathrm{~cm}$ incremental depths from the topsoil using granular

239 using the site-specific van Genuchten water retention curve (Schaap et al. 2001, Gribovszki 2018). Total

240 soil moisture $\left(\mathrm{S}\right.$ in $\left.\mathrm{mm} \mathrm{h}^{-1}\right)$ was computed for the topsoil $(0-30 \mathrm{~cm}$ depth) using the trapezoidal method

241 (Nachabe et al. 2005). S was smoothened using a 3-step moving-average window to gap-fill stray missing

242 values. In-canopy air temperature and relative humidity were recorded (iButton Hygrochrons, Maxim Int.,

243 USA). Air temperature $\left({ }^{\circ} \mathrm{C}\right)$, relative humidity $\left(\mathrm{R}_{\mathrm{h}}\right.$ in $\left.\%\right)$, wind speed $\left(\mathrm{u} \mathrm{in} \mathrm{m} \mathrm{s} \mathrm{s}^{-1}\right)$, and incoming short-wave

244 radiation $\left(\mathrm{R}_{\mathrm{s}}\right.$ in $\left.\mathrm{kW} \mathrm{m}^{-2}\right)$ were recorded using an automatic weather station (AWS) (Vantage-pro Davis Net,

245 USA). Vapour pressure deficit (VPD, $\mathrm{kPa}$ ) was averaged for the separate VPD values calculated from the

246 hourly air temperature and relative humidity data observed by the Hygrochrons and AWS. Precipitation (P 
247 in $\mathrm{mm} \mathrm{h}^{-1}$ ) was recorded using an automated tipping-bucket rain gauge. Reference evapotranspiration ( $\left.\mathrm{E}_{\mathrm{T}}\right)$

248 was computed based on FAO's Penman-Monteith method (FAO56PM, for detailed steps please see Allen

249 et al. 1998), which was reported to be the suitable method for estimating $\mathrm{E}_{\mathrm{T}}$ at the nearby Gangtok in

250 Sikkim (Pandey et al. 2016). Leaf area index (LAI) was extracted for the site from MCD15A3Hv006 level-

2514 product (4-day temporal and $500 \mathrm{~m}$ pixel resolutions) from the Moderate Resolution Imaging

252 Spectroradiometer (MODIS) (Myneni et al. 2015).

\section{Data analysis}

\subsection{Scaling from the probe to stand transpiration}

\subsubsection{Scaling from sap flux density to whole-tree sap flow}

We used a combination of the zero-averaged technique and weighted mean method to estimate

whole-tree sap flow $\left(\mathrm{V}_{\text {rad }}\right.$ in $\left.\mathrm{kg} \mathrm{hr}^{-1}\right)$ in radial trees (for details see Hatton et al. 1990, Pausch et al. 2000).

259 Additionally, sap flow $\left(\mathrm{V}_{\text {rad.2cm }}\right.$ in $\left.\mathrm{kg} \mathrm{hr}^{-1}\right)$ in the radial tree was also estimated assuming homogenous radial

260 flow from $\mathrm{J}$ at $2^{\text {nd }} \mathrm{cm}$ depth $\left(\mathrm{J}_{2 \mathrm{~cm}}\right)$ and total sapwood area $\left(\mathrm{A}_{\text {total }}\right)$ in the tree (equation 2$)$.

$V_{\text {rad. } 2 \mathrm{~cm}}=J_{2 \mathrm{~cm}} * A_{\mathrm{total}} * 10^{-3}$

$262 \mathrm{~V}_{\text {rad.2cm }}$ showed significant overestimation (15\%) in reference to $\mathrm{V}_{\text {rad }}$ suggesting the use of an appropriate

263 scaling mechanism to incorporate the diurnal variability in radial patterns.

264 Studies have used simple linear regression models (LRMs) between integrated whole-tree sap flow $\left(\mathrm{V}_{\mathrm{rad}}\right)$

265 and sap flow in outer xylem for the trees with only outermost sensors $\left(\mathrm{V}_{\text {rad.2cm }}\right)$ (Paudel et al. 2013,

266 Berdanier et al. 2016). However, considering the diurnal variability in their relationships, we chose to

267 develop linear regression models without intercept for each hour of the day (see supplementary data Table

268 S1). The slopes (m) of the LRMs each hour were multiplied with the average of sap flux density at the

269 north $\left(\mathrm{J}_{\text {north }}\right)$ and the south-facing $\left(\mathrm{J}_{\text {south }}\right)$ probes and the total sapwood area $\left(\mathrm{A}_{\text {total }}\right)$ to estimate sap flow

$270\left(\mathrm{~V}_{\text {rep.LM }}\right.$ in $\left.\mathrm{kg} \mathrm{hr}^{-1}\right)$ in the replicate trees $\left(\mathrm{V}_{\text {rep.LM }}\right.$ in $\left.\mathrm{kg} \mathrm{hr}^{-1}\right)$ using equation 3 (Paudel et al. 2013, Berdanier et

271 al. 2016). 
$272 V_{\text {rep.LM }}=\left(\frac{J_{\text {north }}+J_{\text {south }}}{2}\right) * A_{\text {total }} * m * 10^{-3}$

\subsubsection{Scaling from whole-tree sap flow to stand transpiration}

A five-step approach was adopted to scale sap flow $\left(\mathrm{V}\right.$ in $\left.\mathrm{kg} \mathrm{hr}^{-1}\right)$ from the instrumented trees to

276 the stand-level. First, a non-linear least squared (NLS) regression model (intercept $=0.112$, power

277 coefficient $=0.857, P<0.001)$ was fitted between tree diameter $(\mathrm{DBH}$ in $\mathrm{m})$ and sapwood area $\left(\mathrm{A}_{\text {total }}\right.$ in

$278 \mathrm{~m}^{2}$ ) of the 13 trees (see supplementary data Figure S3). The NLS regression model coefficients were used

279 to compute total sapwood are $\left(\mathrm{A}_{\text {total }}\right)$ from $\mathrm{DBH}$ for each tree (above $10 \mathrm{~cm} \mathrm{DBH}$ ) sampled in the

280 vegetation plots in the next step. Third, the instrumented trees were categorized into four DBH classes <

$2810.15 \mathrm{~m}, 0.15-0.19 \mathrm{~m}, 0.20-0.24 \mathrm{~m}$, and $>0.25 \mathrm{~m}$ (see supplementary data Figure S4a). The average sap flux

282 density per class $\left(\mathrm{J}_{\text {avg }}\right)$ was computed by normalizing the $\mathrm{V}$ of each instrumented tree by its $\mathrm{A}_{\text {total }}$ and

283 averaging for each class. Fourth, all trees above $10 \mathrm{~cm}$ DBH sampled in the vegetation plots were

284 categorized into the above-mentioned DBH classes (see supplementary data Figure S4b). Whole-tree sap

285 flow (V) was estimated for each tree in the forest stand by multiplying the corresponding $\mathrm{J}_{\text {avg }}$ of the

286 diameter class with its $\mathrm{A}_{\text {total }}$. Fifth, stand transpiration $\left(\mathrm{T}\right.$ in $\left.\mathrm{mm} \mathrm{h}^{-1}\right)$ was computed by aggregating $\mathrm{V}$ for all

287 trees in the four plots and dividing it by the total plot area. Gap-filling of the missing data for sap flow and

288 environmental variables was consciously avoided due to the strong variability in the existing raw data and

289 mixed results from the modeling exercise detailed later in the manuscript.

\subsubsection{Biases in the estimation of tree sap flow and stand transpiration}

We also estimated biases in whole-tree sap flow for replicate trees using the conventional scaling based on assumptions of uniform radial profile (Kume et al. 2012, Shinohara et al. 2013). The radially

294 uniform sap flow estimate $\left(\mathrm{V}_{\text {rep.CM }}\right.$ in $\left.\mathrm{kg} \mathrm{hr}^{-1}\right)$ was developed using the two diametrically opposite 2-cm

295 probes only without any hourly slope values, thereby ignoring the radial variability (equation 4). Similarly, 
296 whole-tree sap flow ignoring azimuthal variability $\left(\mathrm{V}_{\text {rep.N }}\right.$ in $\left.\mathrm{kg} \mathrm{hr}^{-1}\right)$ was estimated $\mathrm{V}_{\text {rep.N }}$ was estimated

297 using the north-facing probe $\left(\mathbf{J}_{\text {north }}\right.$ ) only without any radial scalars (equation 5). Both the estimates were

298 compared with whole-tree sap flow estimated by incorporating radial variability ( $\left.\mathrm{V}_{\text {rep.LM}}\right)$ as the reference,

299 which was estimated using the hourly slopes of LRMs in equation 3 (Kume et al. 2012, Shinohara et al.

300 2013).

$301 \quad V_{\text {rep.CM }}=\left(\frac{J_{\text {norh }}+J_{\text {south }}}{2}\right) * A_{\text {total }} * 10^{-3}$

302

$V_{\text {rep.N }}=J_{\text {north }} * A_{\text {total }} * 10^{-3}$

303 Both $\mathrm{V}_{\text {rep.CM }}, \mathrm{V}_{\text {rep.N, }}$ and $\mathrm{V}_{\text {rep.LM }}$ were scaled to stand transpiration using the above-mentioned procedure and 304 stand-level biases were estimated.

\subsubsection{Intra and interspecific variability in sap flow}

Four indices were chosen to visualize and quantify radial and azimuthal variabilities (Delzon et al.

308 2004, Fiora and Cescatti 2006, Shinohara et al. 2013):

309 (a) Daily maximum sap flux density $\left(\mathbf{J}_{\max }\right)$ indicated regions of higher activity in the sapwood and was 310 plotted against the depth from the cambium.

311 (b) The percentage contribution of the sapwood annuli at each depth to daily $\mathrm{V}$ was estimated as a product 312 of the sapwood area of the annulus and the corresponding J.

313 (c) Hourly correction factors $\left(\mathrm{C}_{\mathrm{h}}\right)$ was estimated for sunny days in trees with radial probes as the sum of

314 hourly ratios of $\mathrm{J}$ at different depths in reference to $\mathrm{J}_{2 \mathrm{~cm}}$, normalized by the sapwood area of the annulus

$315\left(\mathrm{~A}_{\mathrm{i}}\right)$ over $\mathrm{A}_{\text {total }}$ (Delzon et al. 2004) (equation 6).

316 (d) Sap flow ratios $\left(\mathrm{R}_{\mathrm{NS}}\right)$ were estimated as hourly ratios between $\mathbf{J}_{\text {north }}$ to $\mathbf{J}_{\text {south }}$ in replicate trees with

317 azimuthal probes for all hours (Shinohara et al. 2013).

$318 \quad C_{\mathrm{h}}=\sum_{i=1}^{n}\left(\frac{J_{\mathrm{i}}}{J_{2 \mathrm{~cm}}}\right) *\left(\frac{A_{\mathrm{i}}}{A_{\text {total }}}\right)$ 
319 Species-wise multiple linear regression models (MLRs) were fitted for the day (0600-1700 h) and night

320 (1800-0500 $\mathrm{h}$ ) periods to assess the relative roles of environmental variables $\mathrm{R}_{\mathrm{s}}$, VPD, and $\mathrm{S}$ in driving

321 indices of radial $\left(\mathrm{C}_{\mathrm{h}}\right)$ and azimuthal $\left(\mathrm{R}_{\mathrm{NS}}\right)$ variability (Barbeta et al. 2012). Sap flow between 1800-0500 h

322 was considered nocturnal $\left(\mathrm{V}_{\text {night }}\right)$ and its percentage contribution to daily $\mathrm{V}$ was estimated. Further, $\mathrm{V}_{\text {night }}$

323 was split into evening (1800-2300 h, $\left.\mathrm{V}_{\text {evening }}\right)$ and pre-dawn (0000-0500 h, $\left.\mathrm{V}_{\text {pre-dawn }}\right)$ components (Forster

324 2014). Species-wise MLRs using $\mathrm{V}_{\text {night }}$ as the response variable and VPD, $S$, and wind speed (u) as

325 predictor variables were fitted to understand the environmental drivers of nocturnal sap flow (Barbeta et al.

326 2012). In the abovementioned MLRs, $R_{s}, V P D$, and $S$ were centered on their respective daily means to

327 facilitate the interpretation of the results. Diurnal patterns in sap flow of the three species and stand

328 transpiration were visualized and assessed for variability across seasons.

\subsubsection{Lag analysis between transpiration and SPAC variables}

Lag correlation analysis was used to compute seasonal lag between SPAC variables. The S timeseries was de-trended to remove excessive noise (stlplus function, package stlplus) and the filtered diurnal signals ( $\mathrm{S}_{\mathrm{diu}}$ ) were used (Moore et al. 2011, Gribovszki 2018). Hourly lag was computed (ccf function in R) for each day between the following combinations: $R_{s}$ vs. T, VPD vs. T, and T vs. $S_{\text {diu }}$, and filtered for autocorrelation coefficients (ACF) $>=| \pm 0.4|$ (Komatsu et al. 2010, Moore et al. 2011).

\subsubsection{GLS linear regression model for transpiration}

The relative influences of predictor variables on the response variable were quantified using a

340 combination of a temporal lag model and the Generalized least squares (GLS) regression model ( $\mathrm{gls}$

341 function, package nlme) with a suitable correlational structure. The Generalised least-squared (GLS) 
344 2006, Krishnaswamy et al. 2012). Solar radiation $\left(\mathrm{R}_{\mathrm{s}, \mathrm{kW} \mathrm{m}} \mathrm{k}^{-2}\right)$, Vapour pressure deficit (VPD, $\left.\mathrm{kPa}\right)$, soil

345 moisture $\left(\mathrm{S}, \mathrm{mm} \mathrm{hr}^{-1}\right)$, and Antecedent moisture index $\left(\mathrm{M}_{\mathrm{a}}, \mathrm{mm} \mathrm{hr}^{-1}\right)$ were centered by subtracting the daily

346 mean from the time-series and tested for collinearity. Contiguous subsets longer than 5 days and without

347 any missing values were first tested for temporal lag between the driver-response variables using the cross-

348 correlation function ( $c c f$ in $\mathrm{R}$ ). If any significant lag ( $\mathrm{ACF}>=| \pm 0.2|)$ was observed, the driver variable was

349 lagged by a suitable range of hours to develop multiple lagged time-series starting from zero lag time and a

350 multiple linear regression model was fitted with the response variable. The procedure ware repeated with

351 each of the driver variables and the lagged time-series with the lowest significant lag $(P=<0.05)$ was

352 chosen to develop a reconstituted dataset. The GLS models used the predictors from the reconstituted data

353 for subsequent analysis. The results of GLS models with correlations structures were compared with a

354 similar GLS model without any autocorrelation structure using the Analysis of variance (ANOVA) test.

355 The GLS models with the lowest Akaike information criterion (AIC), higher likelihood ratio, and

356 significance were chosen for interpretations. The transpiration GLS model used $\mathrm{T}$ as the response variable

357 and $\mathrm{R}_{\mathrm{s}}, \mathrm{VPD}$, and $\mathrm{S}$ as predictor variables with second-order autoregressive moving average correlational

358 structure (corARMA). The observed and predicted time-series of transpiration were compared using linear

359 regression models and Gupta-Kling Efficiency (KGE) score to assess the model performances (Gupta and $360 \quad$ Kling 2011).

4. Results

\subsection{Intra and interspecific comparisons of sap flux density and volumetric sap flow}

364 The pioneer species, S. racemosa and E. acuminata, exhibited double rates of sap flux density (J) in 365 comparison to C. hystrix, the late-successional species (Table 3). Whole-tree sap flow (V) increased 366 linearly with total sapwood area across the species $\left(\mathrm{r}^{2}>0.71, P<0.001\right)$. Therefore, S. racemosa and $E$. 367 acuminata, with entire xylem conducting water, transpired at double rates of $C$. hystrix of comparable

368 DBH, which had significant non-conducting heartwood. The peak sap flow in S. racemosa and E.

369 acuminata occurred quite early in the day $(0700-0800 \mathrm{~h})$ whereas $C$. hystrix peaked around noon $(1200 \mathrm{~h})$.

370 the Incidentally, small and medium-sized trees (DBH $<0.2 \mathrm{~m}$ ) contributed to $46 \%$ of $\mathrm{T}$, whereas large- 
371 girthed trees $(\mathrm{DBH}>0.25 \mathrm{~m})$ contributed up to $40 \%$. Radial bias due to assumptions of homogenous flow

372 along the xylem led to an overestimation of V in all three species. However, failure to account for

373 azimuthal variability (azimuthal bias) caused significant underestimation of V in C. hystrix and $S$.

374 racemosa but overestimation in E. acuminata. At the stand-level, failure to account for radial variability

375 overestimated $\mathrm{T}$, whereas azimuthal variability induced significant underestimation.

Table 3. Estimates of sap flux density (J), tree sap flow (V), tree-to-tree coefficient of variation in sap flow

$378(\mathrm{COV})$ in the studied species and at stand-level. Percentage biases in sap flow estimation due to ignoring

radial and azimuthal variability (standard deviation in parentheses) are presented across species and in

380 stand transpiration.

\subsection{Intraspecific variability in sap flow}

Radial patterns in $\mathbf{J}_{\max }$ varied across the three species but remained consistent across the seasons.

385 Both S. racemosa and E. acuminata exhibited concave curves in $\mathrm{J}_{\max }$, with peaks at the outer and innermost

386 xylem (Figure 2a). Correspondingly, the percentage contribution of each depth to daily V declined

387 uniformly from the outermost xylem inwards for S. racemosa and E. acuminata (Figure 2b). Conversely, $C$.

388 hystrix showed the highest $\mathrm{J}_{\max }$ in the inner xylem at $4^{\text {th }} \mathrm{cm}$ depth from the cambium and its contribution to 389 daily V was disproportionately higher (40\%). The importance of the inner xylem in water transport in $C$.

390 hystrix is further corroborated by the highest wood moisture and lowest wood density at $4^{\text {th }} \mathrm{cm}$ depth (see

391 supplementary data Figure S5). Overall, the three species, except E. acuminata, show an increase in mean

392 daily $\mathbf{J}$ with wood moisture and a decline with wood density for a particular sapwood annulus ring (see

393 supplementary data Figure S6). The relative contributions of sapwood rings to whole-tree sap flow

394 remained similar for day and night across the species. Incidentally, the innermost probe at $5^{\text {th }} \mathrm{cm}$ depth in

395 C. hystrix stopped showing any sap flux movement after January, which may be due to the loss of function 
396 as the inner sapwood transitioned into non-functioning heartwood (Moore et al. 2010, Brodersen et al. 2019).

Figure 2. Radial variability in sap flow in the three species along the depth of xylem in (a) average daily maximum sap flux density $\left(\mathbf{J}_{\max }\right)$, and (b) percentage contribution of sap flow at different sapwood depths to daily whole-tree sap flow $\left(\mathrm{V}, \mathrm{kg} \mathrm{hr}^{-1}\right)$ (the error bars represent standard errors). overestimated sap flow $\left(C_{h}>1\right)$ in night-morning $(2300-0900 h)$ and overestimated $\left(C_{h}<1\right)$ in noonevening (1000-2200 h) periods. On a closer look, the variability in $C_{h}$ was driven by the higher sap flux density at outer xylem $\left(1^{\text {st }} \mathrm{cm}\right.$ depth $)$ in $S$. racemosa and E. acuminata, and at inner xylem $\left(4^{\text {th }} \mathrm{cm}\right.$ depth $)$ in C. hystrix to the rest of the xylem. The MLRs results suggested that daytime radial variability $\left(\mathrm{C}_{\mathrm{h}}\right)$ was strongly predicted by $\mathrm{R}_{\mathrm{s}}$ (negative slope) and $\mathrm{S}$ (positive slope) in $S$. racemosa $\left(\mathrm{r}^{2}=0.43, P<0.001\right.$ ) and weakly predicted by $\mathrm{R}_{\mathrm{s}}$ (negative slope) $\left(\mathrm{r}^{2}=0.01, P<0.15\right)$ in $C$. hystrix, whereas none of the predictors were significant for E. acuminata $\left(\mathrm{r}^{2}=0.01, P<0.6\right)$ (see supplementary data Table S2). Conversely, VPD was a strong negative predictor of night $\mathrm{C}_{\mathrm{h}}$ in E. acuminata $\left(\mathrm{r}^{2}=0.4, P<0.001\right)$ and a weak negative predictor in S. racemosa $\left(\mathrm{r}^{2}=0.02, P<0.2\right)$ and $C$. hystrix $\left(\mathrm{r}^{2}=0.001, P<0.6\right)$.

418 Figure 3. Variability in sap flow across the three species in (a) diurnal patterns in correction factor $\left(\mathrm{C}_{\mathrm{h}}\right.$, 419 unitless) used a proxy of radial variability, (b) diurnal patterns in sap flow ratios ( $\mathrm{R}_{\mathrm{NS}}$, unitless) used as a 420 proxy of azimuthal variability. The horizontal dotted lines mark the ideal value (1), and error bars 421 represent standard errors. 
425 the day (Figure 3b). Interestingly, in C. hystrix, the northern probes dominated in the morning and the

426 southern probes afternoon onwards. The MLRs predicting $\mathrm{R}_{\mathrm{NS}}$ performed poorly $\left(\mathrm{r}^{2} \sim 0.03-0.18\right)$ across the

427 species (see supplementary data Table $\mathrm{S} 3$ ). However, $\mathrm{R}_{\mathrm{S}}$ (positive slope) was a significant predictor of $\mathrm{R}_{\mathrm{NS}}$

428 at average VPD and S across the three species $(P<0.09)$. Night-time azimuthal variability was better

429 predicted by VPD $(P<0.06)$ and S $(P<0.08)$ in $S$. racemosa; and by VPD in $C$. hystrix $(P<0.004)$. S was

430 a significant predictor of night $\mathrm{R}_{\mathrm{NS}}$ in E. acuminata $(P<0.04)$.

\subsection{Interspecific variability in sap flow and envrionment}

\subsubsection{Diurnal patterns in sap flow and transpiration in relation to environment}

Both S. racemosa and E. acuminata showed low sap flow at high values of $\mathrm{R}_{\mathrm{s}}$ and VPD (see acuminata followed by C. hystrix and S. racemosa (see supplementary data Table S4).

442 Figure 4. Diurnal patterns of sap flow $\left(\mathrm{V}, \mathrm{kg} \mathrm{hr}^{-1}\right)$, Incoming short-wave radiation $\left(\mathrm{R}_{\mathrm{s}}, \mathrm{kW} \mathrm{m}^{-2}\right)$, and

443 Vapour pressure deficit (VPD, $\mathrm{kPa}$ ) across the three species (values are normalized by their respective daily 444 means for visual scaling and error bars represent standard errors). 
449 fraction of (13.8 $\pm 6 \%)$ of the daily $\mathrm{T}$ with a marginally higher proportion of evening than pre-dawn flux.

450 Across the species, $\mathrm{V}_{\text {night }}$ was concentrated around low VPD $(<0.1 \mathrm{kPa})$, low wind velocity $\left(<0.5 \mathrm{~m} \mathrm{~s}^{-1}\right)$,

451 and moderately saturated soil moisture conditions (see supplementary data Figure S8). The MLR models

452 predicting $\mathrm{V}_{\text {night }}$ concurred with the observations (see supplementary data Table $\mathrm{S} 5$ ). $\mathrm{S}$ (negative slope) was

453 a significant predictor of $\mathrm{V}_{\text {night }}$ in E. acuminata $\left(\mathrm{r}^{2}=0.12, P<0.05\right)$ and VPD (negative slope) was a

454 significant predictor for $C$. hystrix $\left(\mathrm{r}^{2}=0.13, P<0.009\right)$. None of the predictors were significant for $S$.

455 racemosa $\left(\mathrm{r}^{2}=0.02, P>0.5\right)$.

Figure 5 depicts changes in diurnal patterns of SPAC variables from winter to summer as the growing season progressed. The winter (December-February) marked the dry season with bright but cold days, sub-zero night temperatures, low VPD, and declining soil moisture and streamflow. March onwards summer rains started, replenishing the soil moisture reserves and promoting leaf flush. The summers

462 (March-May) saw increased day-length, abundant moisture, warmer temperatures, and higher plant 463 productivity. Consequently, $\mathrm{T}$ also increased from winters to summer peaking in April. The seasonal pattern was corroborated by LAI and PET which peaked in April-May (see supplementary data Figure S9). 
470 to March for E. acuminata and C. hystrix, whereas the corresponding changes were marginal in $S$.

471 racemosa. Azimuthal variability also increased from winter to summers for S. racemosa and E. acuminata,

472 whereas in C. hystrix it was higher in January. Diurnally, the peak sap flow values increased with the

473 growing season, except for S. racemosa, although the timing remained consistent across the species. The

474 bimodal peaks in diurnal sap flow were seasonally consistent for S. racemosa and E. acuminata, with

475 higher rates in the morning than afternoon. However, the weak $\mathrm{V}_{\text {mid-day }}$ behaviour in C. hystrix was

476 restricted to the relatively drier months and shifted to unimodal peaks from March onwards. Weak

477 declining trends in $\mathrm{V}_{\text {night }}$ were observed from dry to wet season in all three species. The diurnal peaks in

$478 \mathrm{~S}_{\mathrm{diu}}$ shifted from afternoon to evening with increasing amplitude from winter to summer. However, simple

479 correlation tests between the SPAC variables yielded low correlations due to temporal lags between the 480 variables.

482 Figure 5. Seasonal changes in diurnal patterns of SPAC variables from winters (December) to summers 483 (May): (a) Incoming short-wave radiation $\left(\mathrm{R}_{\mathrm{s}}\right)$, (b) Vapour Pressure Deficit (VPD), (c) $\mathrm{S}_{\text {diu }}$ is diurnal 484 component of soil moisture, (d), (e) and (f) are the Volumetric sap flow rate (V) of S. racemosa, E. 485 acuminata, and C. hystrix, respectively, and (g) Stand Transpiration (T). Each line represents monthly 486 average values.

\subsection{Environmental controls on transpiration under SPAC}

The cross-correlation analysis explored the shifting lags between SPAC variables across seasons

491 (Figure 6). Positive (negative) autocorrelation coefficient (ACF) values signified that a high (low) value of 492 the driver variable was followed by a high (low) value of the response variable after the corresponding lag493 hours. $T$ consistently lagged behind $\mathrm{R}_{\mathrm{s}}$ and VPD by an average lag of 1-3 $\mathrm{h}$ with a strong positive 494 correlation. However, on days with significant pre-dawn flux, $T$ was ahead of $\mathrm{R}_{\mathrm{s}}$ and VPD by an average of 
495 3-5 $\mathrm{h}$ with strong positive correlations. However, the interactions between $\mathrm{T}$ and $\mathrm{S}_{\mathrm{diu}}$ could be separated 496 into two distinct periods: dry (December-February) and wet (March-May). In the dry period, initially, $\mathrm{S}_{\mathrm{diu}}$

497 led $\mathrm{T}$ by $1-5 \mathrm{~h}$ with a negative correlation but later $\mathrm{T}$ led $\mathrm{S}_{\text {diu }}$ by $3-5 \mathrm{~h}$ with a strong positive correlation.

498 With the advent of rains in March, $\mathrm{T}$ led $\mathrm{S}_{\mathrm{diu}}$ with lags of 2-3 $\mathrm{h}$ but with strong negative correlations.

500 Figure 6. Boxplots showing seasonal shifts in diurnal lag hours at maximum auto-correlation coefficients 501 (ACF) between SPAC variables: Incoming short-wave radiation (Rs, $\mathrm{kW} \mathrm{m-2),} \mathrm{Vapour} \mathrm{pressure} \mathrm{deficit}$ 502 (VPD, $\mathrm{kPa}$ ), stand transpiration (T, mm hr-1) and the diurnal component of soil moisture (Sdiu, mm hr-1). 503 The horizontal dotted line marks zero lag hours. The colour of the boxplot represents the direction of the 504 ACF values.

Three contiguous data periods of 9 days and 16 days lengths in winter, and 24 days length in

508 summer were chosen for modeling transpiration in the system (Table 4). The transpiration GLS model with

509 corARMA structure had significantly lower AIC than their respective GLS models without any

510 correlational structure. The model results showed $R_{\mathrm{s}}$ (positive slope) as a significant predictor of $\mathrm{T}$ at

511 average values of VPD and soil moisture in winters and the significance of $\mathrm{R}_{\mathrm{s}}$ (lower $P$ ) increased as the

512 system became progressively drier. Although VPD was not a significant predictor $(P>0.1)$, the coefficient

513 was negative indicating the limiting role played by VPD, especially at higher values. In the summers, VPD

514 (positive slope) became a significant predictor of $\mathrm{T}$ under average $\mathrm{R}_{\mathrm{s}}$ and $\mathrm{S}$ conditions. $\mathrm{S}$ was not a

515 significant predictor of $\mathrm{T}$, although it is important to note that soil moisture always remained well above the

516 permanent wilting point of the site. The model performance was affected by the inherent variability in sap

517 flow with complex phenomenon like mid-day depression and pre-dawn sap flux dominating the diurnal

518 movements at the site. However, the model results highlight the shifting roles of $\mathrm{R}_{\mathrm{s}}$ and VPD in modulating

519 stand transpiration and thus add to our understanding of plant-water relations in such atypical

520 environments. 
522 Table 4. Results from Generalized least squares (GLS) linear regression model with corARMA

523 correlational structure for transpiration $(* P<0.05$, ** $P<0.01$, *** $P<0.001)$. Predictor variables include

524 Incoming short-wave radiation $\left(\mathrm{R}_{\mathrm{s}}, \mathrm{kW} \mathrm{m}^{-2}\right)$, Vapour Pressure Deficit (VPD, $\left.\mathrm{kPa}\right)$, transpiration $\left(\mathrm{T}, \mathrm{mm} \mathrm{h}^{-1}\right)$ 525 and soil moisture $\left(\mathrm{S}, \mathrm{mm} \mathrm{h}^{-1}\right)$.

\section{Discussion}

The study provides the first detailed understanding of plant water-use by cooccurring pioneers and late-successional species in a very wet high elevation tropical broad-leaved evergreen wet montane forest

530 in Eastern Himalaya. We compare the observed plant-water relations with results and mechanisms from

531 other wet tropical montane forests (TMFs). The intra and interspecific variability in sap flow and

532 transpiration are explored across gradients of size, traits, and canopy positioning, and then analyzed in 533 response to environmental drivers and vegetation characteristics of actively growing secondary TMFs.

534 Further, species composition, in terms of functional groups, canopy structure, and phenology exert a strong 535 influence on differential access of vegetation to solar radiation and soil moisture (Ziegler et al. 2009). We 536 discuss their relative roles in explaining the observed intra and interspecific variability in transpiration. 
546 Not surprisingly, the observed sap flux density $(\mathrm{J})$ in the three species was significantly higher than their

547 respective conspecifics from other TMFs. The observed $\mathrm{J}$ in Castanopsis hystrix at our site (MAP $=4496$

$548 \mathrm{~mm}$ ) was three times higher than conspecific Castanopsis tribuloides from relatively drier (MAP $=1331$

$549 \mathrm{~mm}$ ) Central Himalaya (Ghimire et al. 2014). Similarly, The observed J for Symplocos racemosa and Eurya

550 acuminata were 6-9 times higher than conspecifics in drier environments: Symplocos ramosissma from

551 China (MAP $2000 \mathrm{~mm}$ ) and Symplocos kuroki and Eurya japonica from Japan (MAP $\sim 1700 \mathrm{~mm}$ ),

552 respectively (Chiu et al. 2016, Zhang et al. 2018). The observations of higher sap flux density and sap flow

553 in pioneers (S. racemosa and E. acuminata) than late-successional species (C. hystrix) has been previously

554 reported from tropical lowland secondary forests (1800 masl) of Panama, Costa Rica (40 masl), mid-

555 elevation Ecuadorian Andes ( 2000 masl), and commonly attributed to higher water movement potential of

556 pioneer species (Motzer, Munz, Küppers, and Schmitt 2005, Gutiérrez and Santiago 2006, McCulloh et al.

557 2011). Consequently, the estimated daily transpiration $\left(1.45 \pm 1 \mathrm{~mm} \mathrm{~d}^{-1}\right)$ in relatively wetter Sikkim was also

558 found to be double of drier Central Himalayan oak forests (MAP = $1331 \mathrm{~mm}$ ) in Nepal (Ghimire et al.

559 2014), but comparable with wet low elevation (450- 650 masl) TMFs (MAP $=4200-5000 \mathrm{~mm}$ ) in Costa

560 Rica (Aparecido et al. 2016, Moore et al. 2018) and TMF (MAP = $2067 \mathrm{~mm}$ ) at comparable elevation in

561 Southern Andes (Motzer et al. 2010). The maximum daily stand transpiration (5.3 $\mathrm{mm}$ ) is one of the

562 highest among tropical montane or lowland forests (McJannet et al. 2007, Bruijnzeel et al. 2011). Thus, our

563 site exhibited high transpiration despite being at a higher elevation, possibly fueled by faster growth rates

564 and higher interception losses from the secondary forest vegetation in the relatively wetter climate of

565 Eastern Himalaya (Boyce et al. 2012). The observed radial and azimuthal variability in three species

566 confounded the relationship between sap flux density and tree-based scalars like wood properties, tree size,

567 and form, inducing significant scaling errors (Meinzer et al. 2005, Becker et al. 2012, Berry et al. 2018).

568 Sapwood area was found to be a better bio-scalar of tree to stand transpiration than tree diameter and basal

569 area in mixed-species secondary forests (Kumagai et al. 2005, Berry et al. 2018). 


\section{Confidential manuscript submitted to Trees}

572

573

574

575

576

577

578

579

580

581

582

583

584

585

586

587

588

589

590

591

592

593

594

595

596

597

598

599

The observed nocturnal transpiration $\left(\mathrm{T}_{\text {night }}\right)$ was similar to studies $(\sim 12 \%)$ from China (Siddiq and Cao 2018) and other parts of the globe (Forster 2014, Alvarado-Barrientos et al. 2015) and lower that reports from Mediterranean Europe (35-40 \%) (Barbeta et al. 2012). While most of the nocturnal sap flux occurred in the evening, as reported commonly, pre-dawn flux is an uncommon observation from Himalayan TMFs (Forster 2014). The onset timing (0300-0400 h) during days with pre-dawn flux was similar to reports from Mediterranean Europe (Barbeta et al. 2012). The evening sap flux is commonly attributed to stem refilling and thus is a feature of large trees, although not restricted to them (Zeppel et al. 2011, Siddiq and Cao 2018). Both evening and pre-dawn sap flux were independent of tree size and other drivers were explored. Our observations of 2-3 h of lag between $\mathrm{R}_{\mathrm{s}}$ and VPD and T were seasonally consistent and comparable with reports from TMFs in Costa Rica (Moore et al. 2018) and marginally higher than reports from Tibet ( 1-hour lag) (Wang et al. 2017). The lags may represent delays due to low temperature in winters and leaf wetness in the summers due to night rains or dew (Aparecido et al. 2016, Moore et al. 2018). Although summer rains mostly occurred from noon onwards, a significant part also fell in the pre-dawn period (Kumar et al. 2021). Thus, we recommend incorporating leaf wetness as a variable in any future studies in wet TMFs like Eastern Himalaya, which experiences significant summer rains. Predawn sap flux reflected in the opposite trend of $T$ leading $\mathrm{R}_{\mathrm{s}}$ and VPD, although the peaks and evening $\mathrm{T}$ closely followed $\mathrm{R}_{\mathrm{s}}$ and VPD, suggesting that the decoupling between trunk and crown was limited to the pre-dawn period only (Chen et al. 2016).

Environmental controls on nocturnal sap flux by VPD, leaf wetness, and soil moisture are well documented (Alvarado-Barrientos et al. 2015, Berry et al. 2016, Siddiq and Cao 2018), whereas endogenous stomatal controls have been reported under hydrated night-time conditions of stable VPD and negligible wind (Resco de Dios et al. 2013, De Dios et al. 2015, Chaves et al. 2016). Concurrent observations of high nocturnal sap flux under low VPD, wind, and moderate soil moisture conditions suggest that circadian-driven stomatal control could be a potential explanation, especially for the pre-dawn flux. Kumar et al. (2021) observe a significant diurnal cycle in summer precipitation which starts from noon leaving a much shorter window of 5-6 $\mathrm{h}$ for plant productivity and transpiration. Thus, as proscribed by Barbeta et al. (2012) for Mediterranean Europe, the observed pre-dawn flux could be an adaptation to ensure hydraulic saturation, avoid leaf-level leakage of moisture, and maximise photosynthetic $\mathrm{CO}_{2}$ at the 24 
600 start of the day. The prevalence across both pioneer and late-successional species suggests that pre-dawn

601 flux could be an adaptation to the wet montane forests and merit further investigations. Being the first

602 observations from Himalayan mountains, pre-dawn sap flux holds significance for future SPAC work in

603 terms of shifting the timing of pre-dawn leaf water potential measurements (Kavanagh et al. 2007),

604 estimating water-use efficiency across species (Chaves et al. 2016), hydrological functioning of these

605 forests (Siddiq and Cao 2018) and regional climate change modeling exercises (De Dios et al. 2015).

\subsection{Differential water-use strategies among pioneers and late-successional species}

Functional groups played a major role in driving interspecific variability in transpiration. Pioneer

species (PS) like $S$. racemosa and E. acuminata maintained very high rates of transpiration by maximizing

610 photosynthesis under optimal exposure to solar radiation and soil moisture (Nogueira et al. 2004, Motzer,

611 Munz, Küppers, Schmitt, et al. 2005). Both species also displayed increased radial and azimuthal variability

612 in summers and consistent midday depression. The heightened sensitivity of the pioneer species to

613 environmental extremes is attributed to their canopy position, which exposes them to strong levels of

614 sunlight and VPD triggering midday stomatal closure (Huc et al. 1994, Franco and Lüttge 2002, Chiariello

615 et al. 2006). It is also attributable to their shallow rootedness, although observed topsoil moisture (0-30 cm

616 depth) never went below field capacity. However, pioneer tree species are known to be particularly

617 sensitive to diurnal and seasonal soil moisture fluctuations (Pavlis and Jeník 2000). Seasonal soil moisture

618 stress is known to reduce midday leaf-water potential in Central Himalayan species belonging to the

619 Fagaceae family such as Castanopsis indica, Quercus semicarpifolia, Quercus leucotrichophora, and sub-

620 canopy Rhododendron arboreum (Zobel et al. 2001, Poudyal et al. 2004a, Tewari et al. 2018). However,

621 the absence of significant midday depression in deep-rooted species like C. hystrix at the peak of the dry

622 season and strong diurnal cycles in soil moisture and streamflow (please refer to Chapter 4 section 3.2.4)

623 provide evidence of vegetation accessing moisture from groundwater (Tanaka et al. 2004, Maeght et al.

624 2013, Allen 2014). The observations add empirical evidence to the discussion on the "two worlds

625 hypothesis" by suggesting that deep-rooted trees can access sub-surface soil moisture if available at

626 shallow levels to fuel transpiration demands (McDonnell 2014, Evaristo et al. 2016). Similar comparison 
627 between co-occurring tree species in Semi-arid China has shown high transpiration rates by pioneer

628 species, especially in the growing season (Lyu et al. 2020). The relatively dominant contribution by small

629 and medium-sized trees to $\mathrm{T}$ underlines the importance of conducting more sap flow studies on pioneers,

630 especially in diverse tropical secondary forests (Hornbeck et al. 1997, Nogueira et al. 2004, Moore et al.

631 2018).

632

\subsection{Limitations on sap flow in Eastern Himalaya: Energy vs. Moisture}

Solar radiation and VPD are two key drivers of transpiration when not constrained by moisture

limitations. The study site experienced strong seasonal fluctuations in energy and temperature with

moisture and energy-limited winters. This resultant seasonal variability in the relative roles of sunlight and

VPD as drivers of T has been reported in other TMFs as well (Moore et al. 2018). We observed that solar

radiation was a stronger driver of $\mathrm{T}$ than $\mathrm{VPD}$ and $\mathrm{S}$ in energy-limited winters, similar to report from TMF

639 in Southern Andes (Motzer et al. 2010) and Alps (Fiora and Cescatti 2006), but in contrast to warmer

640 Central Himalaya, where VPD was observed as a stronger driver than solar radiation (Ghimire et al. 2014).

641 However, in summers, VPD became the principal driver of T under abundant energy conditions.

644 theory that the East Himalayan forests are energy-limited under abundant moisture conditions and solar

645 radiation is a significant driver of non-monsoon vegetation activity, as observed by Sebastian et al. (2019)

646 using remotely-sensed enhanced vegetation index (EVI) as a proxy of vegetation productivity. The role of

647 solar radiation is further accentuated in uneven-aged secondary forests in Sikkim, where the social

648 positioning of the trees in the canopy determines the spatial availability of solar radiation to different parts

649 of the crown (Fiora and Cescatti 2006, Küppers et al. 2008, Zhang et al. 2019). This interactive relationship

650 between secondary forest structure dictating the placement of pioneer and emergent in the forest canopy,

651 diurnal shifts in sunlight availability, and plant water-use in a sloped mountain environment is illustrated in

652 Figure 7. 
654 Figure 7. Schematic representation of the interactive relationship between placement of pioneer and 655 emergent in the forest canopy, diurnal shifts in sunlight availability and plant water-use in a typical sloped 656 mountain environment in Himalaya.

\subsection{Influence of secondary forest structure on sap flow variability}

659 The observed Gaussian radial profile with increasing sap flux density in the inner xylem in $C$. 660 hystrix is typical of isolated trees with long crown (Fiora and Cescatti 2006). This is ascribed to higher light 661 availability to the older mid-lower portions of the crown anatomically connected to the inner xylem.

662 Conversely, in trees forming a continuous canopy like S. racemosa and E. acuminata in our case, the lateral 663 foliage activity is suppressed by shading and only the top portion of the crown receives proper light, 664 potentially causing higher sap flux density in the outer xylem. This was highlighted by the overestimation 665 of radial correction factors $\left(\mathrm{C}_{\mathrm{h}}<1\right)$ by outer xylem of in-canopy pioneers like S. racemosa and $E$. 666 acuminata, and underestimation by $\left(\mathrm{C}_{\mathrm{h}}>1\right)$ by outer xylem in emergent trees of $C$. hystrix. Delzon et al. 667 (2004) have observed that the radial correction factors were independent of meteorological factors and 668 better represented the xylem-crown water-use connectivity. Further, in sloped terrains, landscape 669 characteristics like slope and aspect influence diurnal changes in the angle and intensity of incident light, 670 potentially inducing azimuthal variability in sap flow (Kumagai et al. 2007, Chang et al. 2014, Berry et al. 671 2016). Thus, fully exposed crowns of $C$. hystrix exhibited shifting peaks in sap flow from north to south 672 sensors following the NE-SW trajectory of solar radiation, whereas the in-canopy S. racemosa and $E$. 673 acuminata maintained dominant flow at northern probes. Daytime radial and azimuthal variability across

674 the species were attributed to the interaction between the access to solar radiation and soil moisture, 675 whereas night variability was negatively correlated with VPD (Fiora and Cescatti 2006, Shinohara et al. 676 2013). The biases induced by the failure to incorporate azimuthal and radial variability were found to be 677 significant and similar to other studies (Fiora and Cescatti 2006, Kume et al. 2012, Shinohara et al. 2013). 


\section{Confidential manuscript submitted to Trees}

679

680

681

682

683

684

685

686

687

688

689

690

691

692

693

694

695

696

697

698

699

700

701

702

703

704

705

706

\section{Conclusions}

It is still challenging to estimate stand transpiration from sap flow measurements in diverse secondary TMFs because of the variability among different functional groups and diversity in traits that regulate plant-water relations (Huc et al. 1994, Nogueira et al. 2004, Küppers et al. 2008). Radial and azimuthal probes opened a whole new dimension to plant-water use for Himalayan species and their use is highly recommended to reduce errors in estimating stand transpiration (Shinohara et al. 2013, Komatsu et al. 2016). We also highlight the importance of incorporating information on stand structure and tree density while scaling from individuals to stand-level (Küppers et al. 2008). Regardless, the stand transpiration of these East Himalayan wet tropical montane broad-leaved forests has been estimated for the first time using methods covering maximum variability of sap flow using limited resources. Stand transpiration is double of relatively drier Central Himalaya (Ghimire et al. 2014), but at the lower bound of the values reported from tropical montane cloud forests globally, indicating the interactive role of precipitation and elevation in modulating the available energy, moisture, and plant productivity (Bruijnzeel et al. 2011). Owing to the high elevation and cold conditions, solar radiation emerged as the primary driver of transpiration in winters and D in wet summers. Significant nocturnal transpiration dominated by the pre-dawn movement is the first report from the Himalaya. Other adaptations like midday depression in shallow-rooted pioneer species highlight their sensitivity to soil moisture fluctuations. Yet, the deep-rooted Fagaceae species access deeper groundwater and transpired unaffectedly.

Studies on climate change in Eastern Himalaya have predicted an increase in summer rainfall, declining winter rains; and increasing summer and winter temperatures (Kulkarni et al. 2013, Sanjay et al. 2017, Krishnan et al. 2019). Our results suggest that drier and warmer winters are likely to impact the phenology and negatively affect the productivity of shallow-rooted secondary pioneers like $S$. racemosa and E. acuminata, whereas the deep-rooted species like Castanopsis sps. and Himalayan oaks may remain unaffected. The phenological asynchronization can play a critical role in the temporal partitioning of water within different parts of a tree, and between co-occurring species (Francescantonio et al. 2018). Thus, the secondary broad-leaved forests, with the dominance of shallow-rooted pioneers, are more prone to the negative impacts of drier and warmer winters than primary forests, which are dominated by deep-rooted species. In summers, rains provide enough moisture to ensure peak vegetation productivity in April. 
707 However, increased summer precipitation in the future could result in higher cloud cover negatively

708 impacting both vegetation productivity and transpiration leading to increased streamflow in summer (Aston

709 1984, Donohue et al. 2017). Increased summer moisture and cloud cover could also allow the opportunistic

710 fast-growing pioneers to outcompete the late-successional species (Lyu et al. 2020).

711 The overall effect of changes in temperature and precipitation on biodiversity in the region remains 712 complex and requires ecohydrological models specific to the East Himalayan TMFs (Tsering et al. 2010,

713 Asbjornsen et al. 2011). More regional studies inclusive of diurnal and seasonal variability in transpiration

714 will be critical to increasing the accuracy of land-surface interaction models and predicting the impact of

715 climate change on Himalayan ecohydrology (Wang and Dickinson 2012, Miller et al. 2018). It will be

716 worth investigating the role of soil mycorrhizae and root hair densities in facilitating the high transpiration

717 rates observed in these forests (Breda et al. 2006, Carminati et al. 2017). The study provides the first

718 empirical understanding of climatic controls on vegetation water-use from a very wet high elevation

719 tropical broad-leaved evergreen wet montane forest in Eastern Himalaya, one of the 30 global biodiversity

720 hotspots and global 200 ecoregions of importance (Brooks et al. 2006, Chettri et al. 2010). The study

721 contributes to the scant literature on plant-water relations from secondary TMFs where similar species can

722 behave differently than primary forests making generalizations across functional groups, forest types, and

723 climatic conditions highly erroneous (Boyce et al. 2012, Berdanier et al. 2016), and compares the plant-

724 water use strategies between co-existing pioneer and late-successional species (Moore et al. 2018). We

725 recommend prioritizing the conservation and management of these secondary forests in Sikkim for

726 sustained ecosystem services.

727 


\section{Data and Materials Availability}

729 The data that support the findings of this study are available on request from the corresponding author. The

730 data are not publicly available due to privacy or ethical restrictions. A sample subset of the data that

731 support the findings of this study is available in Dryad at (doi:10.5061/dryad.47d7wm3cg) under the

732 citation Kumar (2021). The sample dataset is available for preview at the following url:

733 https://datadryad.org/stash/share/bkDWLqnM4S2C3w0wgri1AcXlyDz3eM2Sgs7prOqLZqk

\section{Authors' Contributions}

736 Manish Kumar did the execution of the study including study design, including testing and modification of

737 the sap flow probes, field investigation, data processing, formal analysis, and original manuscript writing

738 and editing. Yangchenla Bhutia contributed with the vegetation data for scaling up from tree to stand

739 transpiration and helped in vegetation characterisation and manuscript revisions. Dr. Jagdish

740 Krishnaswamy supervised the overall study and generated the requisite funds and resources. Dr. Gladwin

741 Joseph and Dr. Jagdish Krishnaswamy helped in the conceptualization, sap flow probe designing, field

742 investigation, and reviewing and editing the manuscript. 


\section{Conflict of interest}

745 The authors have no relevant financial or non-financial interests to disclose.

746

747 Funding

748 Department of Biotechnology, Govt. of India (GoI) (Grant No. BT/01/NE/PS/NCBS/09); National Mission

749 for Himalayan Studies (NMHS), Ministry of Environment, Forest and Climate Change, GoI (Grant No:

750 GBPI/NMHS/HF/RA/2015-16/).

\section{Acknowledgments}

753

The authors thank the Department of Forests, Environment and Wildlife Management, Rural Management

754 and Development Department, and Home Department, Govt. of Sikkim, India, and the Indian Army for

755 research permits and field support. The study would not have been possible without the able field support

756 from Passang Tamang, Girish Varma, Naresh Rai, the staff of Fambong-Loh Wildlife Sanctuary. The

757 authors thank Dr. Nachiket Kelkar and Dr. Aniruddha Marathe for their useful comments on the statistical

758 analysis. The authors are indebted to Prof. Nathan G. Phillips at Boston University, USA, Prof. Frederick

759 Meinzer at Oregon State University, USA, and Forests Science Laboratory (Corvallis), the USA for

760 generously sharing the original thermal dissipation probe assembly design. The authors acknowledge the

761 logistical support provided by ATREE Regional Office, Gangtok during the study.

\section{Authors' Contributions}

764 Manish Kumar: Conceptualization, Methodology, Manufacturing, Testing and modification of the sap

765 flow probes, Investigation, Software, Formal analysis, Visualization, Writing - Original draft preparations.

766 Yangchenla Bhutia: Investigation, Writing - Review \& Editing. Gladwin Joseph: Conceptualization,

767 Methodology, Testing and modification of the sap flow probes, Writing - Review \& Editing. Jagdish 
768 Krishnaswamy: Conceptualization, Methodology, Testing and modification of the sap flow probes,

769 Writing - Review \& Editing, Supervision, Project Administration, Funding acquisition.

770

$771 \quad$ References

Acharya BK, Chettri B, Vijayan L (2011) Distribution pattern of trees along an elevation gradient of Eastern Himalaya, India. Acta Oecologica 37:329-336.

http://linkinghub.elsevier.com/retrieve/pii/S1146609X1100049X (21 May 2013, date last accessed ).

Ackerly DD, Dudley SA, Sultan SE, Schmitt J, Coleman JS, Linder CR, Sandquist DR, Geber MA, Evans ANNS, Dawson TE, Lechowicz MJ (2000) The Evolution of Plant Ecophysiological Traits : Recent Advances and Future Directions. Bioscience 50

Allen MF (2014) How Oaks Respond to Water Limitation. Gen Tech Rep PSW-GTR-251 Berkeley, CA US Dep Agric For Serv Pacific Southwest Res Stn 251:13-22.

https://www.fs.usda.gov/treesearch/pubs/49910

Allen RG, Pereira LS, Raes D, Smith M (1998) Crop evapotranspiration: Guidelines for computing crop requirements. Irrig Drain Pap No 56, FAO:300.

http://www.kimberly.uidaho.edu/water/fao56/fao56.pdf

Alvarado-Barrientos MS, Holwerda F, Geissert DR, Muñoz-Villers LE, Gotsch SG, Asbjornsen H, Dawson TE (2015) Nighttime transpiration in a seasonally dry tropical montane cloud forest environment. Trees - Struct Funct 29:259-274. http://www.scopus.com/inward/record.url?eid=2-s2.084925534897\&partnerID=tZOtx3y1

Aparecido LMT, Miller GR, Cahill AT, Moore GW (2016) Comparison of tree transpiration under wet and dry canopy conditions in a Costa Rican premontane tropical forest. Hydrol Process 30:5000-5011.

Asbjornsen H, Goldsmith GR, Alvarado-Barrientos MS, Rebel K, Van Osch FP, Rietkerk M, Chen J, Gotsch S, Tobón C, Geissert DR, Gómez-Tagle A, Vache K, Dawson TE (2011) Ecohydrological 
advances and applications in plant-water relations research: A review. J Plant Ecol 4:3-22. http://jpe.oxfordjournals.org/cgi/doi/10.1093/jpe/rtr005 (1 March 2013, date last accessed ).

Aston AR (1984) The effect of doubling atmospheric CO2 on streamflow: A simulation. J Hydrol 67:273280. https://www.sciencedirect.com/science/article/pii/0022169484902464

Bajracharya B, Chettri N, Choudhury D, Oli KP, Shakya B, Sharma E, Thapa R, Uddin K (2010) Biodiversity in the Eastern Himalayas: Status, Trends and Vulnerability to Climate Change: Climate Change Impact and Vulnerability in the Eastern Himalayas - Technical Report 2. Books:28. http://lib.icimod.org/record/26847

Barbeta A, Ogaya R, Peñuelas J (2012) Comparative study of diurnal and nocturnal sap flow of Quercus ilex and Phillyrea latifolia in a Mediterranean holm oak forest in Prades (Catalonia, NE Spain). Trees - Struct Funct 26:1651-1659.

Barbour MM, Hunt JE, Walcroft AS, Rogers GND, McSeveny TM, Whitehead D (2005) Components of ecosystem evaporation in a temperate coniferous rainforest, with canopy transpiration scaled using sapwood density. New Phytol 165:549-558.

Barros AP, Lang TJ (2003) Monitoring the Monsoon in the Himalayas: Observations in Central Nepal, June 2001. Mon Weather Rev 131:1408-1427. https://journals.ametsoc.org/doi/pdf/10.1175/15200493(2003)131\%3C1408\%3AMTMITH\%3E2.0.CO\%3B2

Becker GS, Braun D, Gliniars R, Dalitz H (2012) Relations between wood variables and how they relate to tree size variables of tropical African tree species. Trees - Struct Funct 26:1101-1112. https://idp.springer.com/authorize/casa?redirect_uri=https://link.springer.com/article/10.1007/s00468 $-012-0687-$

6\&casa_token=TrJpBnWiH_IAAAAA:UweCk13DKo_JUaiXBW4w7KPntigiAToqUledC265Sqw83 XE81cMNV7kUw5eqVhgzhr2XDrHF1LmSxc6M

Berdanier AB, Miniat CF, Clark JS (2016) Predictive models for radial sap flux variation in coniferous, diffuse-porous and ring-porous temperate trees. Tree Physiol:tpw027. 
http://treephys.oxfordjournals.org/lookup/doi/10.1093/treephys/tpw027

Berry ZC, Gotsch SG, Holwerda F, Muñoz-Villers LE, Asbjornsen H (2016) Slope position influences vegetation-atmosphere interactions in a tropical montane cloud forest. Agric For Meteorol 221:207218. https://www.sciencedirect.com/science/article/pii/S0168192316301678

Berry ZC, Looker N, Holwerda F, Gómez Aguilar LR, Ortiz Colin P, González Martínez T, Asbjornsen H (2018) Why size matters: The interactive influences of tree diameter distribution and sap flow parameters on upscaled transpiration. Tree Physiol 38:264-276.

Bhutia Y, Gudasalamani R, Ganesan R, Saha S (2019) Assessing forest structure and composition along the altitudinal gradient in the state of Sikkim, Eastern Himalayas, India. Forests 10:1-17.

Bookhagen B, Burbank DW (2010) Toward a complete Himalayan hydrological budget: Spatiotemporal distribution of snowmelt and rainfall and their impact on river discharge. J Geophys Res 115:F03019. http://www.agu.org/pubs/crossref/2010/2009JF001426.shtml (27 February 2013, date last accessed ).

Boyce RL, Durtsche RD, Fugal SL (2012) Impact of the invasive shrub Lonicera maackii on stand transpiration and ecosystem hydrology in a wetland forest. Biol Invasions 14:671-680.

Breda N, Huc R, Granier A, Dreyer E (2006) Temperate forest trees and stands under severe drought: a review of ecophysiological responses, adaptation processes and long-term consequences. Ann For Sci 63:625-644.

Brodersen CR, Roddy AB, Wason JW, McElrone AJ (2019) Functional Status of Xylem Through Time. Annu Rev Plant Biol 70:1-27.

Brooks TM, Mittermeier RA, Da Fonseca GAB, Gerlach J, Hoffmann M, Lamoreux JF, Mittermeier CG, Pilgrim JD, Rodrigues ASL (2006) Global biodiversity conservation priorities. Science (80- ) 313:58-61.

Brown S, Hall M, Gregory W, Lugo AE (2019) Tropical Secondary Forests. 6:1-32.

Bruijnzeel LA, Mulligan M, Scatena FN (2011) Hydrometeorology of tropical montane cloud forests: 
Emerging patterns. Hydrol Process 25:465-498. http://doi.wiley.com/10.1002/hyp.7974 (10 March 2013, date last accessed ).

Buytaert W, Celleri R, Willems P, Bièvre B De, Wyseure G (2006) Spatial and temporal rainfall variability in mountainous areas: A case study from the south Ecuadorian Andes. J Hydrol 329:413-421.

Carminati A, Passioura JB, Zarebanadkouki M, Ahmed MA, Ryan PR, Watt M, Delhaize E (2017) Root hairs enable high transpiration rates in drying soils. New Phytol:771-781.

Célleri R, Feyen J (2009) The Hydrology of Tropical Andean Ecosystems: Importance, Knowledge Status, and Perspectives. Mt Res Dev 29:350-355.

Čermák J, Kučera J, Nadezhdina N (2004) Sap flow measurements with some thermodynamic methods, flow integration within trees and scaling up from sample trees to entire forest stands. Trees - Struct Funct 18:529-546. http://link.springer.com/10.1007/s00468-004-0339-6 (14 October 2013, date last accessed ).

Chan AM, Bowling DR (2017) Assessing the thermal dissipation sap flux density method for monitoring cold season water transport in seasonally snow-covered forests. Tree Physiol 37:984-995.

Chand DB, Poudyal K, Jha PK (2017) SHIFTS IN LEAF PHENOLOGY OF THREE HIMALAYAN OAK SPECIES: ROLE OF WOOD WATER PROPERTIES. ECOPRINT:29-36.

Chang X, Zhao W, He Z (2014) Radial pattern of sap flow and response to microclimate and soil moisture in Qinghai spruce (Picea crassifolia) in the upper Heihe River Basin of arid northwestern China. Agric For Meteorol 187:14-21. http://dx.doi.org/10.1016/j.agrformet.2013.11.004

Chaves MM, Costa JM, Zarrouk O, Pinheiro C, Lopes CM, Pereira JS (2016) Controlling stomatal aperture in semi-arid regions-The dilemma of saving water or being cool? Plant Sci 251:54-64. http://dx.doi.org/10.1016/j.plantsci.2016.06.015

Chen YJ, Bongers F, Tomlinson K, Fan ZX, Lin H, Zhang S Bin, Zheng YL, Li YP, Cao KF, Zhang JL (2016) Time lags between crown and basal sap flows in tropical lianas and co-occurring trees. Tree 
Physiol 36:736-747.

Chettri N, Shakya B, Thapa R, Sharma E (2010) Status of a protected area system in the Hindu KushHimalayas : An analysis of PA coverage. Int J Biodivers Sci Manag 1604:37-41.

Chettri N, Sharma E, Deb DC, Sundriyal RC (2002) Impact of Firewood Extraction on Tree Structure, Regeneration and Woody Biomass Productivity in a Trekking Corridor of the Sikkim Himalaya. Mt Res Dev 22:150-158.

Chiariello NR, Field CB, Mooney HA (2006) Midday Wilting in a Tropical Pioneer Tree. Funct Ecol 1:3.

Chiu C-W, Komatsu H, Katayama A, Otsuki K (2016) Scaling-up from tree to stand transpiration for a warm-temperate multi-specific broadleaved forest with a wide variation in stem diameter. J For Res 21:161-169. http://link.springer.com/10.1007/s10310-016-0532-7

Davis TW, Kuo C-M, Liang X, Yu P-S (2012) Sap flow sensors: construction, quality control and comparison. Sensors (Basel) 12:954-71. http://www.pubmedcentral.nih.gov/articlerender.fcgi?artid=3279248\&tool=pmcentrez\&rendertype=a bstract (27 August 2012, date last accessed ).

Delzon S, Sartore M, Granier A, Loustau D (2004) Radial profiles of sap flow with increasing tree size in maritime pine. Tree Physiol 24:1285-1293.

De Dios VR, Roy J, Ferrio JP, Alday JG, Landais D, Milcu A, Gessler A (2015) Processes driving nocturnal transpiration and implications for estimating land evapotranspiration. Sci Rep 5:1-8. http://dx.doi.org/10.1038/srep10975

Donohue RJ, Roderick ML, McVicar TR, Yang Y (2017) A simple hypothesis of how leaf and canopylevel transpiration and assimilation respond to elevated $\mathrm{CO} 2$ reveals distinct response patterns between disturbed and undisturbed vegetation. J Geophys Res Biogeosciences 122:168-184.

Evaristo J, Mcdonnell JJ, Scholl MA, Bruijnzeel LA, Chun KP (2016) Insights into plant water uptake from xylem-water isotope measurements in two tropical catchments with contrasting moisture conditions. 
Hydrol Process 3227:3210-3227.

Federer CA (1973) Forest transpiration greatly speeds streamflow recession. Water Resour Res 9:1599_ 1604. http://onlinelibrary.wiley.com/doi/10.1029/WR009i006p01599/full (9 January 2015, date last accessed ).

Fiora A, Cescatti A (2006) Diurnal and seasonal variability in radial distribution of sap flux density: Implications for estimating stand transpiration. Tree Physiol 26:1217-1225.

Forrester DI (2015) Transpiration and water-use efficiency in mixed-species forests versus monocultures: Effects of tree size, stand density and season. Tree Physiol 35:289-304.

Forster MA (2014) How significant is nocturnal sap flow? Tree Physiol 34:757-765.

Francescantonio D di, Villagra M, Goldstein G, Campanello PI (2018) Leaf phenology and water-use patterns of canopy trees in Northern Argentinean subtropical forests. Tree Physiol 38:1841-1854.

Franco AC, Lüttge U (2002) Midday depression in savanna trees: Coordinated adjustments in photochemical efficiency, photorespiration, $\mathrm{CO} 2$ assimilation and water use efficiency. Oecologia $131: 356-365$.

Ghimire CP, Lubczynski MW, Bruijnzeel LA, Chavarro-Rincón D (2014) Transpiration and canopy conductance of two contrasting forest types in the Lesser Himalaya of Central Nepal. Agric For Meteorol 197:76-90. http://dx.doi.org/10.1016/j.agrformet.2014.05.012

Giambelluca TW (2002) Hydrology of altered tropical forest. Hydrol Process 16:1665-1669.

Granier A (1987) Evaluation of transpiration in a Douglas-fir stand by means of sap flow measurements. Tree Physiol 3:309-20. http://www.ncbi.nlm.nih.gov/pubmed/14975915

Gribovszki Z (2018) Comparison of specific-yield estimates for calculating evapotranspiration from diurnal groundwater-level fluctuations. Hydrogeol J 26:869-880.

Gupta HV, Kling H (2011) On typical range, sensitivity, and normalization of Mean Squared Error and 
Nash-Sutcliffe Efficiency type metrics. Water Resour Res 47:2-4.

Gutiérrez M V., Santiago LS (2006) A comparison of sap flow measurements and potometry in two tropical lowland tree species with contrasting wood properties. Rev Biol Trop 54:73-81.

Guyot A, Ostergaard KT, Fan J, Santini NS, Lockington DA (2015) Xylem hydraulic properties in subtropical coniferous trees influence radial patterns of sap flow: implications for whole tree transpiration estimates using sap flow sensors. Trees - Struct Funct 29:961-972.

Harmon T (2009) Sap-Happy Sap flow probe construction and use. 2009 PASI-PASEO Course Read Present:1-9. https://eng.ucmerced.edu/paseo/paseo-reading-documents/erics-energy-balance-sapflow-session/Sap-Happy.pdf

Hatton TJ, Catchpole EA, Vertessy RA (1990) Integration of sap flow velocity to estimate plant water use. Tree Physiol 6:201-209.

Hatton TJ, Moore SJ, Reece PH (1995) Estimating stand transpiration in a Eucalyptus populnea woodland with the heat pulse method: measurement errors and sampling strategies. Tree Physiol 15:219-27. http://www.ncbi.nlm.nih.gov/pubmed/14965961

Heimann M, Reichstein M (2008) Terrestrial ecosystem carbon dynamics and climate feedbacks. Nature 451:289-292.

Hernandez-Santana V, Hernandez-Hernandez A, Vadeboncoeur MA, Asbjornsen H (2015) Scaling from single-point sap velocity measurements to stand transpiration in a multispecies deciduous forest: uncertainty sources, stand structure effect, and future scenarios. Can J For Res 45:1489-1497. http://www.nrcresearchpress.com/doi/10.1139/cjfr-2015-0009

Hetherington AM, Woodward FI (2003) The role of stomata in sensing and driving environmental change. Nature 424:901-8. http://www.ncbi.nlm.nih.gov/pubmed/12931178

Hornbeck JW, Martin CW, Eagar C (1997) Summary of water yield experiments at Hubbard Brook Experimental Forest, New Hampshire. Can J For Res 27:2043-2052. 
Huc R, Ferhi A, Guehl JM (1994) Pioneer and late stage tropical rainforest tree species (French Guiana) growing under common conditions differ in leaf gas exchange regulation, carbon isotope discrimination and leaf water potential. Oecologia 99:297-305.

James S a, Clearwater MJ, Meinzer FC, Goldstein G (2002) Heat dissipation sensors of variable length for the measurement of sap flow in trees with deep sapwood. Tree Physiol 22:277-83. http://www.ncbi.nlm.nih.gov/pubmed/11874724

Kanade R, John R (2018) Topographical influence on recent deforestation and degradation in the Sikkim Himalaya in India; Implications for conservation of East Himalayan broadleaf forest. Appl Geogr 92:85-93. https://doi.org/10.1016/j.apgeog.2018.02.004

Kavanagh KL, Pangle R, Schotzko AD (2007) Nocturnal transpiration causing disequilibrium between soil and stem predawn water potential in mixed conifer forests of Idaho. In: Tree Physiology.pp 621-629.

Komatsu H, Onozawa Y, Kume T, Tsuruta K, Kumagai T, Shinohara Y, Otsuki K (2010) Stand-scale transpiration estimates in a Moso bamboo forest: II. Comparison with coniferous forests. For Ecol Manage 260:1295-1302. http://dx.doi.org/10.1016/j.foreco.2010.07.012

Komatsu H, Shinohara Y, Kume T, Tsuruta K, Otsuki K (2016) Does measuring azimuthal variations in sap flux lead to more reliable stand transpiration estimates? Hydrol Process:n/a-n/a. http://doi.wiley.com/10.1002/hyp.10780

Krishnan R, Shrestha AB, Ren G, Rajbhandari R, Saeed S, Sanjay J, Syed A, Vellore R, Xu Y, You Q, Ren Y (2019) Unravelling Climate Change in the Hindu Kush Himalaya: Rapid Warming in the Mountains and Increasing Extremes. In: Wester P, Mishra A, Mukherji A, Shrestha AB, Change C (eds) The Hindu Kush Himalaya Assessment. Springer International Publishing. http://dx.doi.org/10.1007/978-3-319-92288-1_3

Krishnaswamy J, Bonell M, Venkatesh B, Purandara BK, Lele S, Kiran MC, Reddy V, Badiger S, Rakesh KN (2012) The rain-runoff response of tropical humid forest ecosystems to use and reforestation in the western ghats of India. J Hydrol 472-473:216-237. 
http://linkinghub.elsevier.com/retrieve/pii/S0022169412008190 (25 May 2013, date last accessed ).

Kulkarni A, Patwardhan S, Kumar KK, Ashok K, Krishnan R (2013) High-resolution Regional Climate Model PRECIS Projected Climate Change in the Hindu Kush - Himalayan Region By Using the High-resolution Regional Climate Model PRECIS. Mt Res Dev 33:142-151.

Kumagai T, Aoki S, Shimizu T, Otsuki K (2007) Sap flow estimates of stand transpiration at two slope positions in a Japanese cedar forest watershed. Tree Physiol 27:161-8. http://www.ncbi.nlm.nih.gov/pubmed/17241959

Kumagai T, Nagasawa H, Mabuchi T, Ohsaki S, Kubota K, Kogi K, Utsumi Y, Koga S, Otsuki K (2005) Sources of error in estimating stand transpiration using allometric relationships between stem diameter and sapwood area for Cryptomeria japonica and Chamaecyparis obtusa. For Ecol Manage 206:191-195. http://linkinghub.elsevier.com/retrieve/pii/S0378112704008114 (1 March 2013, date last accessed ).

Kumar M, Hodnebrog Ø, Sophie Daloz A, Sen S, Badiger S, Krishnaswamy J (2021) Measuring precipitation in Eastern Himalaya: Ground validation of eleven satellite, model and gauge interpolated gridded products. J Hydrol 599

Kume T, Otsuki K, Du S, Yamanaka N, Wang Y-L, Liu G-B (2012) Spatial variation in sap flow velocity in semiarid region trees: its impact on stand-scale transpiration estimates. Hydrol Process 26:11611168. http://doi.wiley.com/10.1002/hyp.8205 (3 March 2013, date last accessed ).

Küppers M, Motzer T, Schmitt D, Ohlemacher C, Zimmermann R, Horna V, Küppers BIL, Mette T (2008) Stand Structure, Transpiration Responses in Trees and Vines and Stand Transpiration of Different Forest Types Within the Mountain Rainforest. In: Gradients in a Tropical Mountain Ecosystem of Ecuador.pp 149-156.

Li Y, Liu J, Chen G, Zhou G, Huang W, Yin G, Zhang D, Li Y (2013) Water-use efficiency of four native trees under $\mathrm{CO} 2$ enrichment and $\mathrm{N}$ addition in subtropical model forest ecosystems. J Plant Ecol $8: 411-419$. 
Lu P, Urban L, Ping Z (2004) Granier's Thermal Dissipation Probe ( TDP ) Method for Measuring Sap Flow in Trees : Theory and Practice. Acta Bot Sin 46:631-646.

Lyu J, He QY, Yang J, Chen QW, Cheng RR, Yan MJ, Yamanaka N, Du S (2020) Sap flow characteristics in growing and non-growing seasons in three tree species in the semiarid Loess Plateau region of China. Trees - Struct Funct 34:943-955. https://doi.org/10.1007/s00468-020-01972-1

Mackay DS, Ewers BE, Loranty MM, Kruger EL (2010) On the representativeness of plot size and location for scaling transpiration from trees to a stand. J Geophys Res Biogeosciences 115:n/a-n/a. http://doi.wiley.com/10.1029/2009JG001092 (1 March 2013, date last accessed ).

Maeght J, Rewald B, Pierret A (2013) How to study deep roots — and why it matters. Front Plant Sci 4:114.

Manzoni S, Vico G, Porporato A, Katul G (2013) Biological constraints on water transport in the soilplant-atmosphere system. Adv Water Resour 51:292-304. http://linkinghub.elsevier.com/retrieve/pii/S0309170812000711 (6 March 2013, date last accessed ).

McCulloh KA, Meinzer FC, Sperry JS, Lachenbruch B, Voelker SL, Woodruff DR, Domec JC (2011) Comparative hydraulic architecture of tropical tree species representing a range of successional stages and wood density. Oecologia 167:27-37.

McDonnell JJ (2014) The two water worlds hypothesis: ecohydrological separation of water between streams and trees? Wiley Interdiscip Rev Water 1:323-329.

http://onlinelibrary.wiley.com/doi/10.1002/wat2.1027/abstract\%5Cnhttp://onlinelibrary.wiley.com/do i/10.1002/wat2.1027/abstract;jsessionid=2F0FB27BEA54C92DA9D99EEDC2B9AD3D.f02t03?deni edAccessCustomisedMessage $=\&$ userIsAuthenticated $=$ true

McJannet, D., Fitch P, Disher M, Wallace J (2007) Measurements of transpiration in four tropical rainforest types of north Queensland, Australia. Hydrol Process 21:3549-3564.

Meinzer FC, Bond BJ, Warren JM, Woodruff DR (2005) Does water transport scale universally with tree size? Funct Ecol 19:558-565. 
Mencuccini M, Manzoni S, Christoffersen B (2019) Modelling water fluxes in plants: from tissues to biosphere. New Phytol 222:1207-1222.

Miller G, Moore G, Cahill A (2018) Improving Land-Surface Modeling of Evapotranspiration Processes in Tropical Forests. (No DOE-TAMU-10654) Texas A\&M Eng Exp Stn

Moore GW, Bond BJ, Jones J a., Meinzer FC (2010) Thermal-dissipation sap flow sensors may not yield consistent sap-flux estimates over multiple years. Trees - Struct Funct 24:165-174.

Moore GW, Jones JA, Bond BJ (2011) How soil moisture mediates the influence of transpiration on streamflow at hourly to interannual scales in a forested catchment. Hydrol Process 25:3701-3710. http://doi.wiley.com/10.1002/hyp.8095 (28 March 2013, date last accessed ).

Moore GW, Orozco G, Aparecido LMT, Miller GR (2018) Upscaling transpiration in diverse forests: Insights from a tropical premontane site. Ecohydrology 11:1-13.

Motzer T, Munz N, Anhuf D, Küppers M (2010) Transpiration and microclimate of a tropical montane rain forest, southern Ecuador. In: Bruijnzeel L. A., Scatena F. N. HLS (ed) Tropical Montane Cloud Forests: Science for Conservation and Management. Cambridge University Press, pp 447-455.

Motzer T, Munz N, Küppers M, Schmitt D (2005) Stomatal conductance, transpiration and sap flow of tropical montane rain forest trees in the southern Ecuadorian Andes. Tree Physiol:1283-1293. http://eutils.ncbi.nlm.nih.gov/entrez/eutils/elink.fcgi?dbfrom=pubmed\&id=16076777\&retmode=ref\& cmd=prlinks\%5Cnpapers2://publication/uuid/2A413717-66F3-4BF9-A6F3-F7D88866D4BF

Motzer T, Munz N, Küppers M, Schmitt D, Anhuf D (2005) Stomatal conductance, transpiration and sap flow of tropical montane rain forest trees in the southern Ecuadorian Andes. Tree Physiol 25:12831293.

Myneni R, Knyazikhin Y, Park T (2015) MOD15A2H MODIS Leaf Area Index/FPAR 8-Day L4 Global 500m SIN Grid V006.

Nachabe M, Shah N, Ross M, Vomacka J (2005) Evapotranspiration of Two Vegetation Covers in a 
Shallow Water Table Environment. Soil Sci Soc Am J 69:492.

https://www.soils.org/publications/sssaj/abstracts/69/2/0492

Neumann RB, Cardon ZG (2012) The magnitude of hydraulic redistribution by plant roots: A review and synthesis of empirical and modeling studies. New Phytol 194:337-352. http://onlinelibrary.wiley.com/store/10.1111/j.1469-8137.2012.04088.x/asset/j.1469-

8137.2012.04088.x.pdf?v=1\&t=j97seo5n\&s=bdf1a66181fe12e836f42c59ee7c797d1338cb02

Nogueira A, Martinez CA, Ferreira LL, Prado CHBA (2004) Photosynthesis and water use efficiency in twenty tropical tree species of differing succession status in a Brazilian reforestation. Photosynthetica 42:351-356.

Ohsawa M, Shakya PR, Numata M (1986) Distribution and Succession of West Himalayan Forest Types in the Eastern Part of the Nepal Himalaya. Mt Res Dev 6:143-157.

Pandey PK, Dabral PP, Pandey V (2016) Evaluation of reference evapotranspiration methods for the northeastern region of India. Int Soil Water Conserv Res 4:52-63. http://dx.doi.org/10.1016/j.iswcr.2016.02.003

Patle GT, Sengdo D, Tapak M (2020) Trends in major climatic parameters and sensitivity of evapotranspiration to climatic parameters in the eastern Himalayan Region of Sikkim, India. J Water Clim Chang 11:491-502.

Paudel I, Kanety T, Cohen S (2013) Inactive xylem can explain differences in calibration factors for thermal dissipation probe sap flow measurements. Tree Physiol 33:986-1001.

Pausch RC, Grote EE, Dawson TE (2000) Estimating water use by sugar maple trees: considerations when using heat-pulse methods in trees with deep functional sapwood. Tree Physiol 20:217-227. http://www.ncbi.nlm.nih.gov/pubmed/12651458

Pavlis J, Jeník J (2000) Roots of pioneer trees in amazonian rain forest. Trees - Struct Funct 14:442-455.

Phillips NG, Lewis JD, Logan BA, Tissue DT (2010) Inter- and intra-specific variation in nocturnal water 
transport in Eucalyptus. Tree Physiol 30:586-596.

Phillips N, Oren R, Zimmermann R (1996) Radial patterns of xylem sap flow in non-, diffuse- and ringporous tree species. Plant, Cell Environ 19:983-990.

Piedallu C, Gégout J-C, Perez V, Lebourgeois F (2013) Soil water balance performs better than climatic water variables in tree species distribution modelling. Glob Ecol Biogeogr 22:470-482. http://doi.wiley.com/10.1111/geb.12012 (3 June 2013, date last accessed ).

Pinheiro JC, Bates D. (2006) Mixed-Effects Models in S and S-PLUS. Springer Sci Bus Media:250-270.

Poudyal K, Jha PK, Zobel DB, Thapa CB (2004a) Patterns of leaf conductance and water potential of five Himalayan tree species. Tree Physiol 24:689-699.

Poudyal K, Jha PK, Zobel DB, Thapa CB (2004b) Patterns of leaf conductance and water potential of five Himalayan tree species. Tree Physiol 24:689-99. http://www.ncbi.nlm.nih.gov/pubmed/15059769

QGIS.org (2021) QGIS Geographic Information System. Open Source Geospatial Foundation Project. http://qgis.osgeo.org

R Core Team (2021) R: A language and environment for statistical computing. R Foundation for Statistical Computing, Vienna, Austria. http://www.r-project.org/.\%0A

Ramakrishnan PS, Kushwaha SPS (2001) Secondary forests of the Himalaya with emphasis on the northeastern hill region of India. J Trop For Sci:727-747.

Resco de Dios V, Díaz-Sierra R, Goulden ML, Barton CVM, Boer MM, Gessler A, Ferrio JP, Pfautsch S, Tissue DT (2013) Woody clockworks: Circadian regulation of night-time water use in Eucalyptus globulus. New Phytol 200:743-752.

RStudio Team (2021) RStudio: Integrated Development for R. RStudio, Inc., Boston, MA. http://www.rstudio.com/.

Sanjay J, Krishnan R, Shrestha AB, Rajbhandari R, Ren GY (2017) Downscaled climate change 
projections for the Hindu Kush Himalayan region using CORDEX South Asia regional climate models. Adv Clim Chang Res 8:185-198. https://doi.org/10.1016/j.accre.2017.08.003

Schaap MG, Leij FJ, Van Genuchten MT (2001) Rosetta: A computer program for estimating soil hydraulic parameters with hierarchical pedotransfer functions. J Hydrol 251:163-176.

Schlesinger W, Jasechko S (2014) Transpiration in the global water cycle. Agric For Meteorol 189190:115-117.

Schulze E-D, Robichaux RH, Grace J, Rundel PW, Ehleringer JR (1987) Plant water balance. Bioscience 37:1-9. http://www.jstor.org/stable/1310175

Sebastian DE, Ganguly S, Krishnaswamy J, Du K, Nemani R, Ghosh S (2019) Multi-Scale Association between Vegetation Growth and Climate in India : A Wavelet Analysis Approach. Remote Sens 11:2073.

Sharma CL, Sharma M, Carter MJ, Kharkongor BM (2011) Inter species wood variation of Castanopsis species of Meghalaya. J Indian Acad Wood Sci 8:124-129.

Shinohara Y, Tsuruta K, Ogura A, Noto F, Komatsu H, Otsuki K, Maruyama T (2013) Azimuthal and radial variations in sap flux density and effects on stand-scale transpiration estimates in a Japanese cedar forest. Tree Physiol 33:550-558.

Shrestha KB, Hofgaard A, Vandvik V (2015) Tree-growth response to climatic variability in two climatically contrasting treeline ecotone areas, central Himalaya, Nepal. Can J For Res 45:16431653.

Siddiq Z, Cao KF (2018) Nocturnal transpiration in 18 broadleaf timber species under a tropical seasonal climate. For Ecol Manage 418:47-54. http://dx.doi.org/10.1016/j.foreco.2017.12.043

Singh SP, Tewari A, Singh SK, Pathak GC (2000) Significance of phenologically asynchronous populations of the central Himalayan oaks in drought adaptation. Curr Sci 79:353-357.

Singh S, Zobel D, Garkoti S (2006) Patterns in water relations of central Himalayan trees. Trop ... 47:15945 
182. http://tropecol.com/pdf/open/PDF_47_2/kp47201.pdf (11 August 2013, date last accessed ).

Singh SP, Zobel DB, Garkoti SC, Tewari A, Negi CMS (2006) Patterns in water relations of central Himalayan trees. Trop Ecol 47:159-182.

Sudhakar S, Prasad PRC, Arrawatia ML, Sudha K, Babar S, Rajeshwar Rao SKSV (2008) Landscape analysis in Fambong Lho wildlife sanctuary, east district, Sikkim, India using remote sensing and GIS techniques. J Indian Soc Remote Sens 36:203-216.

Sundriyal RC, Sharma E (1996) Anthropogenic pressure on tree structure and biomass in the temperate forest of Mamlay watershed in Sikkim. For Ecol Manage 81:113-134.

Sundriyal RC, Sharma E (2003) Underutilized edible plants of the Sikkim Himalaya: Need for domestication. Curr Sci 85:731-736.

Suzuki M, Noshiro S, Takahashi A, Yoda K, Joshi L (1991) WOOD STRUCTURE OF HIMALAYAN PLANTS , II. In: Ohba H, Malla SB (eds) The Himalayan Plants Volume 2. Tokio: The University Museum, The University of Tokyo, pp 1-118. http://umdb.um.utokyo.ac.jp/DKankoub/Bulletin/no34/no34005.html

Tambe S, Arrawatia ML, Ganeriwala AK (2012) Managing Rural Development in the Mountain State of Sikkim, India. Mt Res Dev 32:242-252. http://www.bioone.org/doi/abs/10.1659/MRD-JOURNALD-12-00005.1

Tambe S, Arrawatia ML, Sharma N (2011) Assessing the Priorities for Sustainable Forest Management in the Sikkim Himalaya, India: A Remote Sensing Based Approach. J Indian Soc Remote Sens 39:555564. http://link.springer.com/10.1007/s12524-011-0110-6 (7 May 2013, date last accessed ).

Tanaka K, Takizawa H, Kume T, Xu J, Tantasirin C, Suzuki M (2004) Impact of rooting depth and soil hydraulic properties on the transpiration peak of an evergreen forest in northern Thailand in the late dry season. J Geophys Res D Atmos 109:1-10.

Tang X, Li H, Desai AR, Nagy Z, Luo J, Kolb TE, Olioso A, Xu X, Yao L, Kutsch W, Pilegaard K, 
Köstner B, Ammann C (2014) How is water-use efficiency of terrestrial ecosystems distributed and changing on Earth? Sci Rep 4:1-11.

Tewari A, Bhatt J, Mittal A (2016) Influence of tree water potential in inducing flowering in Rhododendron arboreum in the central Himalayan region. IForest 9:842-846.

Tewari A, Shah S, Singh N, Mittal A (2018) Treeline species in western himalaya are not water stressed: A comparison with low elevation species. Trop Ecol 59:313-325.

Todd JM, Muneepeerakul R, Pumo D, Azaele S, Miralles-Wilhelm F, Rinaldo a., Rodriguez-Iturbe I (2010) Hydrological drivers of wetland vegetation community distribution within Everglades National Park, Florida. Adv Water Resour 33:1279-1289.

http://dx.doi.org/10.1016/j.advwatres.2010.04.003

Troch PA, Martinez GF, Pauwels VRN, Sivapalan M, Harman C, Brooks PD, Gupta H (2009) Climate and vegetation water use efficiency at catchment scales. Hydrol Process 2414:2409-2414.

Tsering K, Sharma E, Chettri N, Shrestha A (2010) Climate Change Impact and Vulnerability in the Eastern Himalayas - Synthesis Report 2 ICIMOD. Icimod:110.

Wang K, Dickinson RE (2012) A review of global terrestrial evapotranspiration: Observation, modeling, climatology, and climatic variability. Rev Geophys 50:1-54.

Wang H, He K, Li R, Sheng Z, Tian Y, Wen J, Chang B (2017) Impact of time lags on diurnal estimates of canopy transpiration and canopy conductance from sap-flow measurements of Populus cathayana in the Qinghai-Tibetan Plateau. J For Res 28:481-490.

Wiedemann A, Marañón-Jiménez S, Rebmann C, Herbst M, Cuntz M (2016) An empirical study of the wound effect on sap flux density measured with thermal dissipation probes. Tree Physiol 36:14711484.

Wohl E, Barros A, Brunsell N, Chappell NA, Coe M, Giambelluca T, Goldsmith S, Harmon R, Hendrickx JMH, Juvik J, McDonnell J, Ogden F (2012) The hydrology of the humid tropics. Nat Clim Chang 
2:655-662. http://dx.doi.org/10.1038/nclimate1556

Zeppel MJB, Lewis JD, Medlyn B, Barton CVM, Duursma RA, Eamus D, Adams MA, Phillips N, Ellsworth DS, Forster MA, Tissue DT (2011) Interactive effects of elevated CO2 and drought on nocturnal water fluxes in Eucalyptus saligna. Tree Physiol 31:932-944.

https://academic.oup.com/treephys/article-lookup/doi/10.1093/treephys/tpr024

Zhang X, Wang Y, Wang Y, Zhang S, Zhao X (2019) Effects of social position and competition on tree transpiration of a natural mixed forest in Chongqing, China. Trees - Struct Funct 0:0. http://dx.doi.org/10.1007/s00468-019-01811-y

Zhang Z, Zhao P, Zhao X, Zhou J, Zhao P, Zeng X, Hu Y, Ouyang L (2018) The tree height-related spatial variances of tree sap flux density and its scale-up to stand transpiration in a subtropical evergreen broadleaf forest. Ecohydrology 11:1-12.

Ziegler H, Weber J, Lüttge UE (2009) Thermal dissipation probe measurements of sap flow in the xylem of trees documenting dynamic relations to variable transpiration given by instantaneous weather changes and the activities of a mistletoe xylem parasite. Trees - Struct Funct 23:441-450.

Zobel DB, Garkoti SC, Singh SP, Tewari A, Negi CMS (2001) Patterns of water potential among forest types of the central Himalaya. Curr Sci 80:774-779.

http://tejas.serc.iisc.ernet.in/ currsci/mar252001/774.pdf (11 August 2013, date last accessed ). 


\section{List of figures}

\begin{tabular}{ll}
\hline $\begin{array}{l}\text { Figure } \\
\text { No. }\end{array}$ & Caption \\
\hline & Figure 1: (a) Digital elevation model (DEM) map of Sikkim showing; (b) the elevation profile \\
& of the Fambong-Lho wildlife sanctuary (FWS) and (c) delineated catchment maps of FMBL \\
1 & stream in FWS. The maps are prepared in QGIS (QGIS.org 2021) using the ASTERGDEM \\
& 003 (elevation in meters). \\
& Figure 2. Radial variability in sap flow in the three species along the depth of xylem in (a) \\
& average daily maximum sap flux density $\left(\mathrm{J}_{\max }\right)$, and (b) percentage contribution of sap flow at \\
& different sapwood depths to daily whole-tree sap flow $\left(\mathrm{V}, \mathrm{kg} \mathrm{hr}^{-1}\right)$ (the error bars represent \\
& standard errors).
\end{tabular}

Figure 3. Variability in sap flow across the three species in (a) diurnal patterns in correction factor $\left(\mathrm{C}_{\mathrm{h}}\right.$, unitless) used a proxy of radial variability, (b) diurnal patterns in sap flow ratios ( $\mathrm{R}_{\mathrm{NS}}$, unitless) used as a proxy of azimuthal variability. The horizontal dotted lines mark the ideal value (1) and error bars represent standard errors.

Figure 4. Diurnal patterns of sap flow $\left(\mathrm{V}, \mathrm{kg} \mathrm{hr}^{-1}\right)$, Incoming short-wave radiation (Rs, $\mathrm{kW} \mathrm{m}^{-}$

$\left.4 \quad{ }^{2}\right)$ and Vapour pressure deficit (VPD, $\mathrm{kPa}$ ) across the three species (values are normalized by their respective daily means for visual scaling and error bars represent standard errors).

Figure 5. Seasonal changes in diurnal patterns of SPAC variables from winters (December) to summers (May): (a) Incoming short-wave radiation $\left(\mathrm{R}_{\mathrm{s}}\right)$, (b) Vapour Pressure Deficit (VPD),

5 (c) $\mathrm{S}_{\mathrm{diu}}$ is diurnal component of soil moisture, (d), (e) and (f) are the Volumetric sap flow rate (V) of S. racemosa, E. acuminata and C. hystrix, respectively, and (g) Stand Transpiration (T). Each line represents monthly average values.

Figure 6. Seasonal shifts in diurnal lag hours at maximum auto-correlation coefficients (ACF) between SPAC variables: (a) Incoming short-wave radiation $\left(\mathrm{R}_{\mathrm{s}}, \mathrm{kW} \mathrm{m}^{-2}\right)$ leading stand 6 transpiration $\left(\mathrm{T}, \mathrm{mm} \mathrm{h}^{-1}\right)$, (b) Vapour pressure deficit (VPD, $\mathrm{kPa}$ ) leading $\mathrm{T}$, and (c) T leading the diurnal component of soil moisture $\left(\mathrm{S}_{\mathrm{diu}}, \mathrm{mm} \mathrm{h}^{-1}\right)$. The horizontal dotted line marks zero 
lag hours. Symbol size and type represent the magnitude and direction of ACF values, respectively.

Figure 7. Pictorial representation of the interactive relationship between placement of pioneer

7 and emergent in the forest canopy, diurnal shifts in sunlight availability and plant water-use in a typical sloped mountain environment in Himalaya. 


\section{List of tables}

\section{Table}

No.

\section{Title}

Life-forms and ecophysiological characteristics of the three species used for sap flow
measurements.
Biometric details ( \pm standard deviation) of the three species instrumented for sap flow
measurements along with the total number of data days and number of radial probes installed
per species.
Estimates of sap flux density $(\mathrm{J})$, tree sap flow $(\mathrm{V})$, tree-to-tree coefficient of variation in sap
flow (COV) in the studied species and at stand-level. Percentage biases in sap flow estimation
due to ignoring radial and azimuthal variability $($ standard deviation in parentheses) are
presented across species and in stand transpiration.
Results from Generalized least squares $(\mathrm{GLS})$ linear regression model with corARMA
correlational structure for transpiration $(* P<0.05, * * P<0.01, * * * P<0.001)$. Predictor
variables include Incoming short-wave radiation $\left(\mathrm{R}_{\mathrm{s}}, \mathrm{kW} \mathrm{m}^{-2}\right)$, Vapour Pressure Deficit $(\mathrm{VPD}$,
$\mathrm{kPa})$, transpiration $\left(\mathrm{T}, \mathrm{mm} \mathrm{h}^{-1}\right)$ and soil moisture $\left(\mathrm{S}, \mathrm{mm} \mathrm{h}^{-1}\right)$.




\section{Figures}
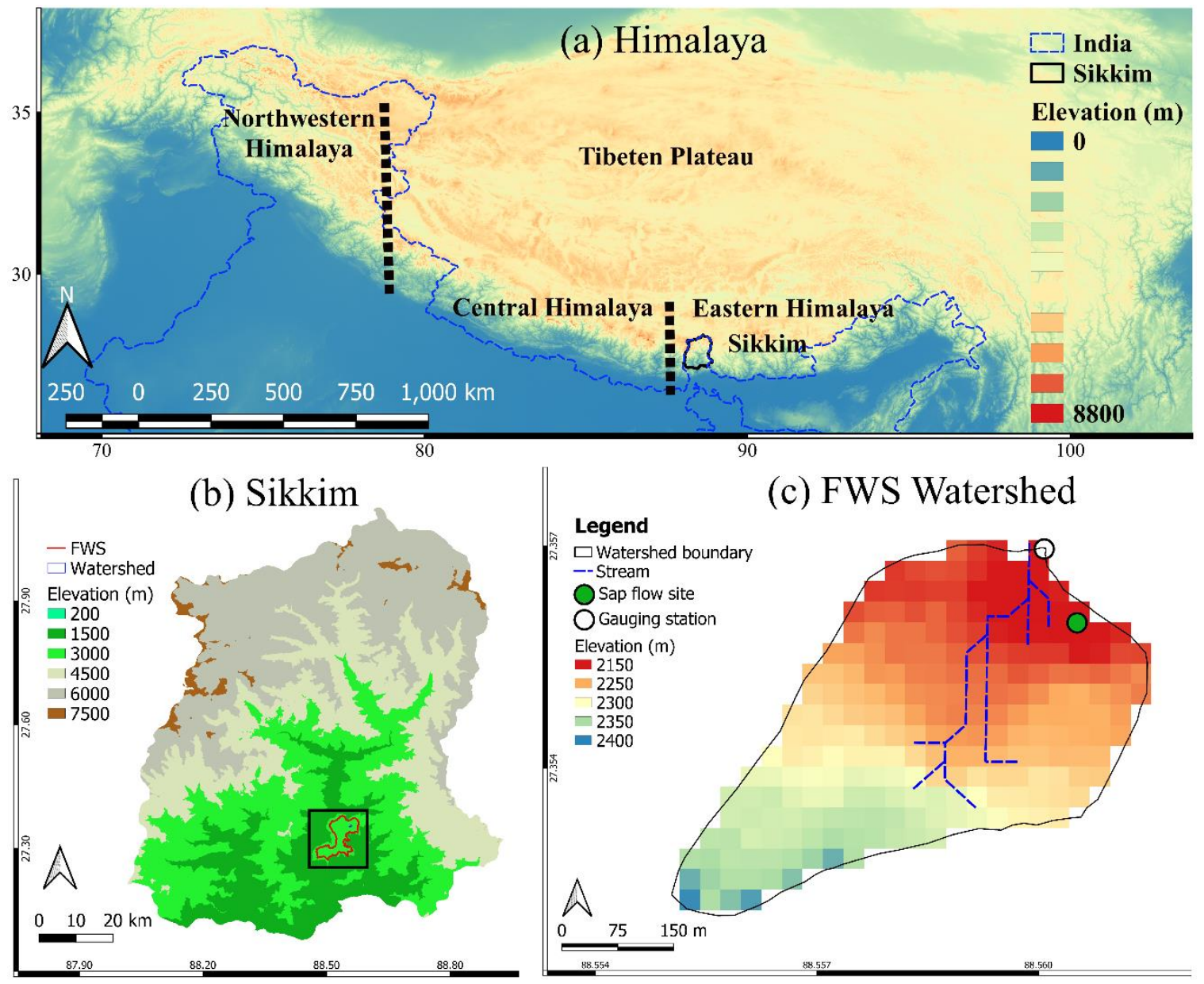

Figure 1: (a) Digital elevation model (DEM) map of Sikkim showing; (b) the elevation profile of the Fambong-Lho wildlife sanctuary (FWS) and (c) delineated catchment maps of FMBL stream in FWS. The maps are prepared in QGIS (QGIS.org 2021) using the ASTERGDEM 003 (elevation in meters). 

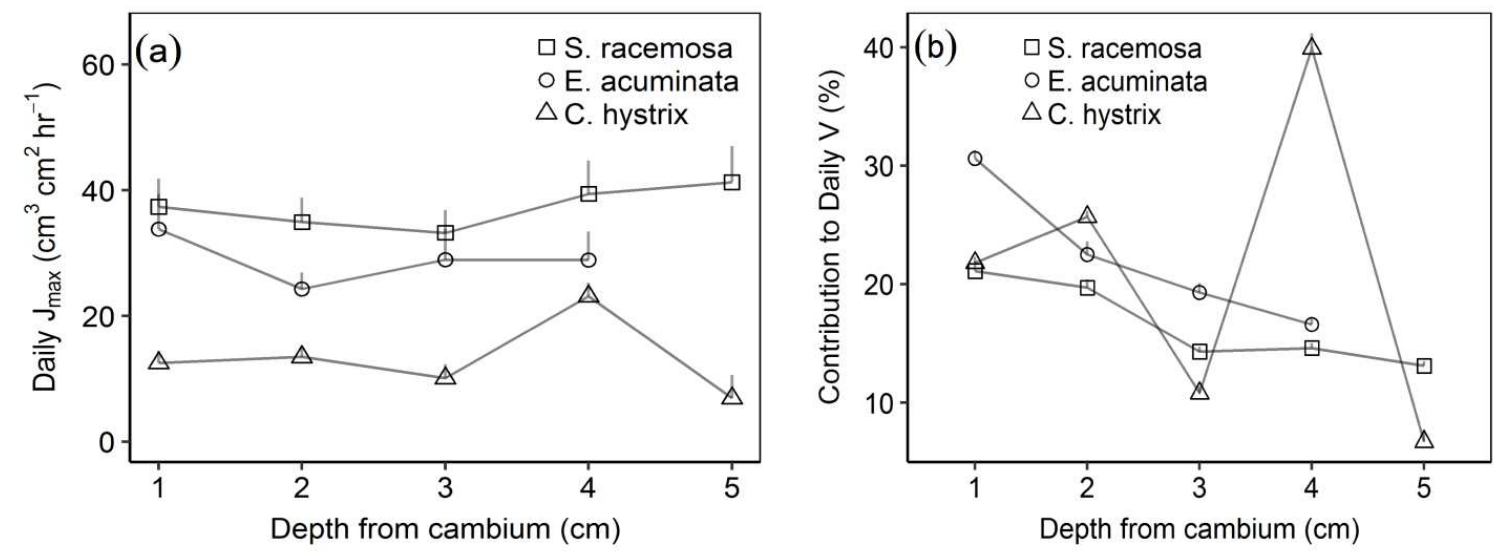

Figure 2. Radial variability in sap flow in the three species along the depth of xylem in (a) average daily maximum sap flux density $\left(\mathbf{J}_{\max }\right)$, and (b) percentage contribution of sap flow at different sapwood depths to daily whole-tree sap flow $\left(\mathrm{V}, \mathrm{kg} \mathrm{hr}^{-1}\right)$ (the error bars represent standard errors). 

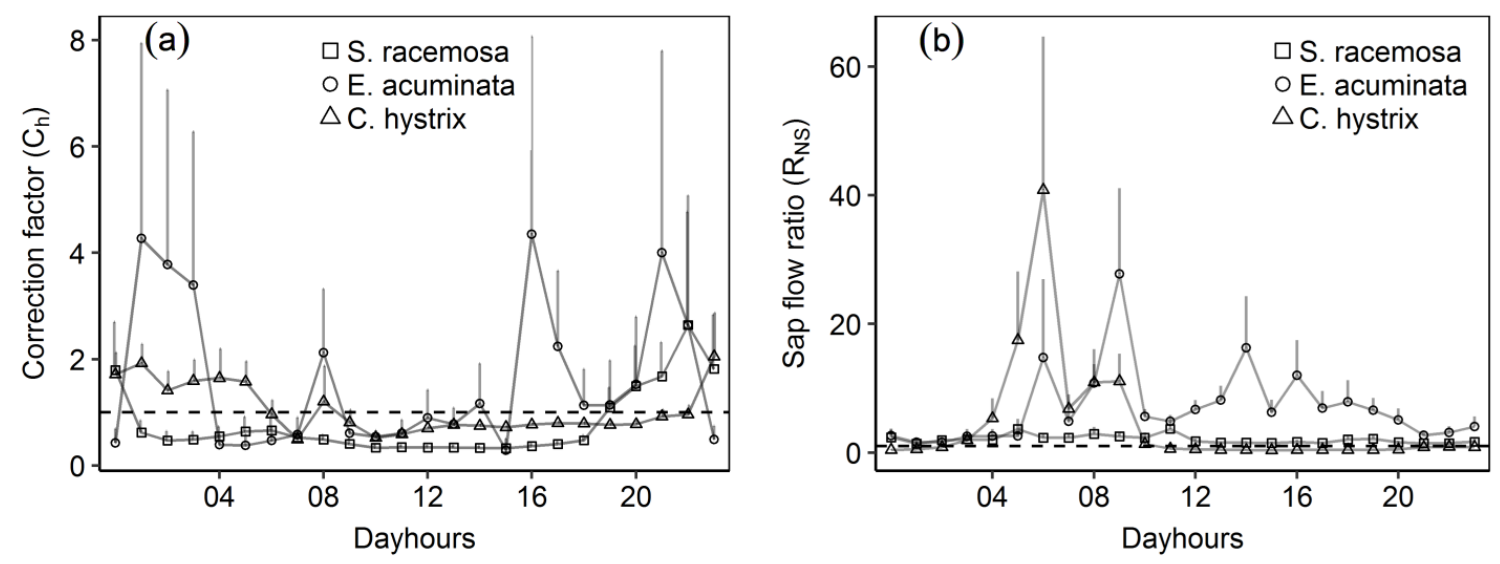

Figure 3. Variability in sap flow across the three species in (a) diurnal patterns in correction factor $\left(\mathrm{C}_{\mathrm{h}}\right.$, unitless) used a proxy of radial variability, (b) diurnal patterns in sap flow ratios ( $\mathrm{R}_{\mathrm{NS}}$, unitless) used as a proxy of azimuthal variability. The horizontal dotted lines mark the ideal value (1) and error bars represent standard errors. 
(a) S. racemosa

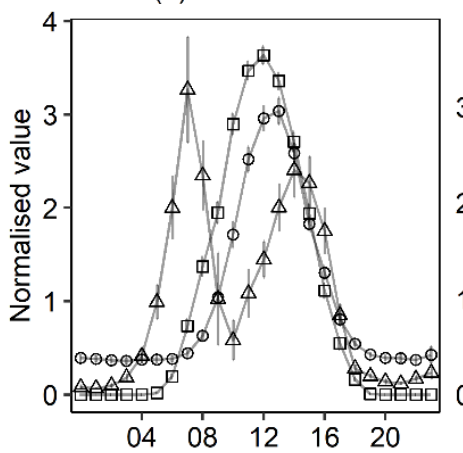

(b) E. acuminata

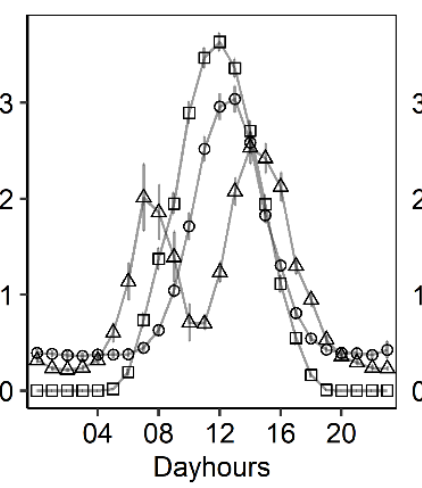

(c) C. hystrix

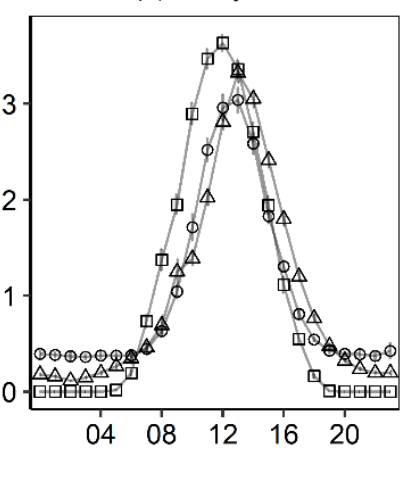

Variable

$\square \quad \mathrm{R}_{\mathrm{s}}$

$\circ \quad$ VPD

$\triangle \quad \vee$

Figure 4. Diurnal patterns of sap flow $\left(\mathrm{V}, \mathrm{kg} \mathrm{hr}^{-1}\right)$, Incoming short-wave radiation (Rs, $\mathrm{kW} \mathrm{m}^{-2}$ ) and Vapour pressure deficit (VPD, $\mathrm{kPa}$ ) across the three species (values are normalized by their respective daily means for visual scaling and error bars represent standard errors). 
(a) $\mathrm{R}_{\mathrm{s}}\left(\mathrm{kW} \mathrm{m}^{-2}\right)$

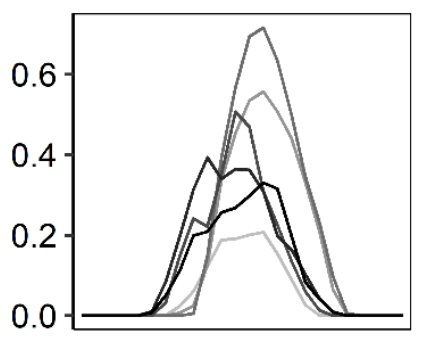

(d) $V_{\mathrm{S} \text {. racemosa }}\left(\mathrm{kg} \mathrm{hr}^{-1}\right)$

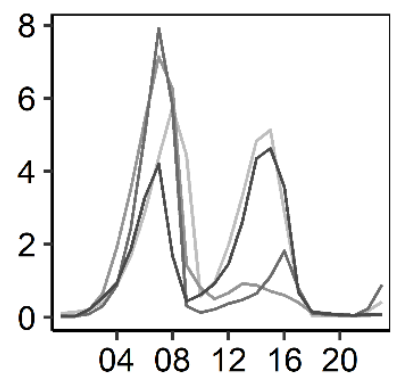

(b) $\mathrm{D}(\mathrm{kPa})$

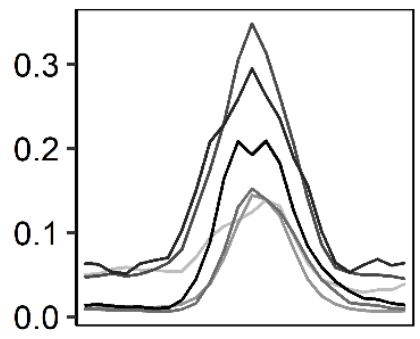

(e) $V_{E \text {. acuminata }}\left(\mathrm{kg} \mathrm{hr}^{-1}\right)$

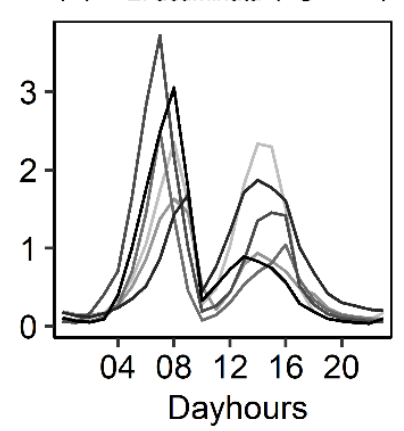

(c) $\mathrm{S}_{\text {diu }}\left(\mathrm{mm} \mathrm{hr}^{-1}\right)$

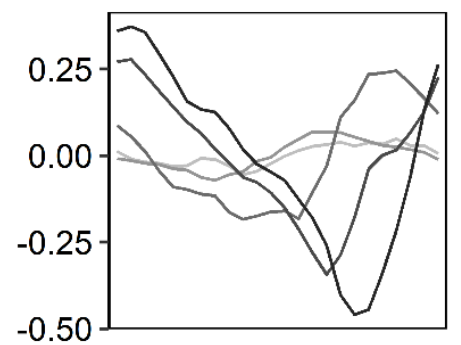

Months

- Dec

- Jan

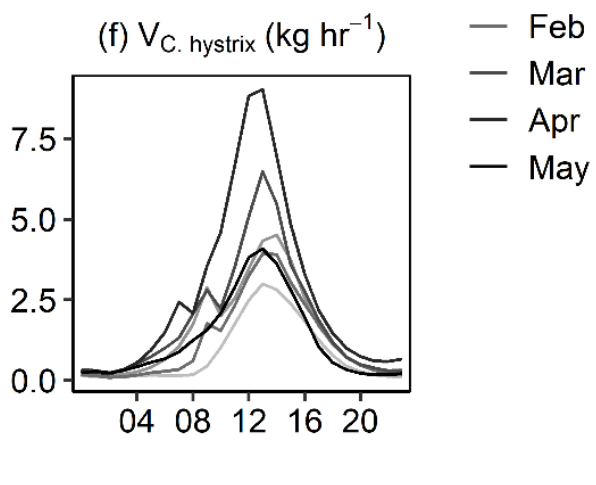

Figure 5. Seasonal changes in diurnal patterns of SPAC variables from winters (December) to summers (May): (a) Incoming short-wave radiation $\left(\mathrm{R}_{\mathrm{s}}\right.$ ), (b) Vapour Pressure Deficit (VPD), (c) $\mathrm{S}_{\text {diu }}$ is diurnal component of soil moisture, (d), (e) and (f) are the Volumetric sap flow rate (V) of S. racemosa, E. acuminata and C. hystrix, respectively, and (g) Stand Transpiration (T). Each line represents monthly average values. 
(a) $R_{s}$ vs $T$

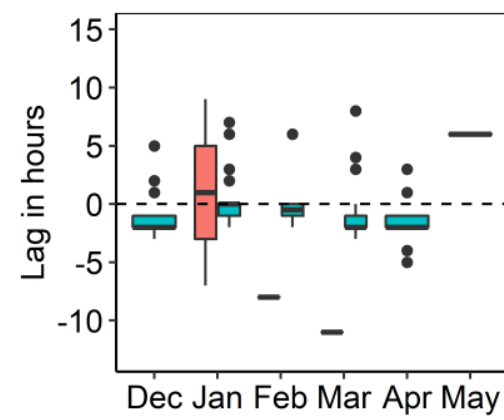

(b) D vs T

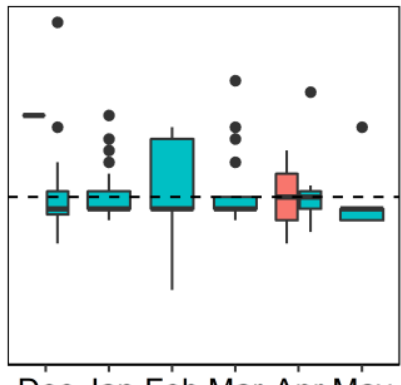

Dec Jan Feb Mar Apr May Year (2013-2014) (c) $T$ vs $S_{\text {diu }}$

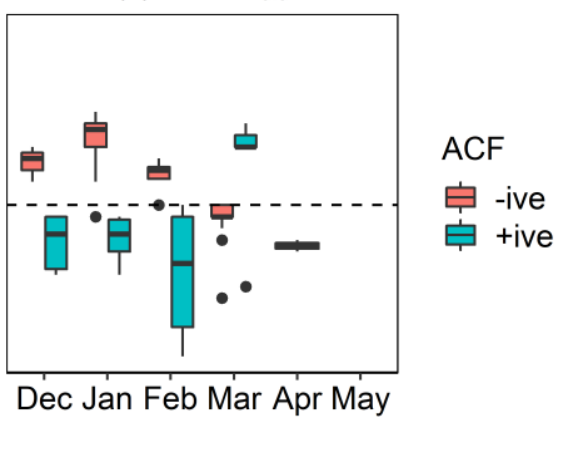

Figure 6. Boxplots showing seasonal shifts in diurnal lag hours at maximum auto-correlation coefficients (ACF) between SPAC variables: Incoming short-wave radiation (Rs, $\mathrm{kW} \mathrm{m-2),} \mathrm{Vapour} \mathrm{pressure} \mathrm{deficit}$ (VPD, $\mathrm{kPa}$ ), stand transpiration ( $\mathrm{T}, \mathrm{mm} \mathrm{hr}-1$ ) and the diurnal component of soil moisture (Sdiu, $\mathrm{mm} \mathrm{hr}-1$ ). The horizontal dotted line marks zero lag hours. The colour of the boxplot represents the direction of the ACF values. 

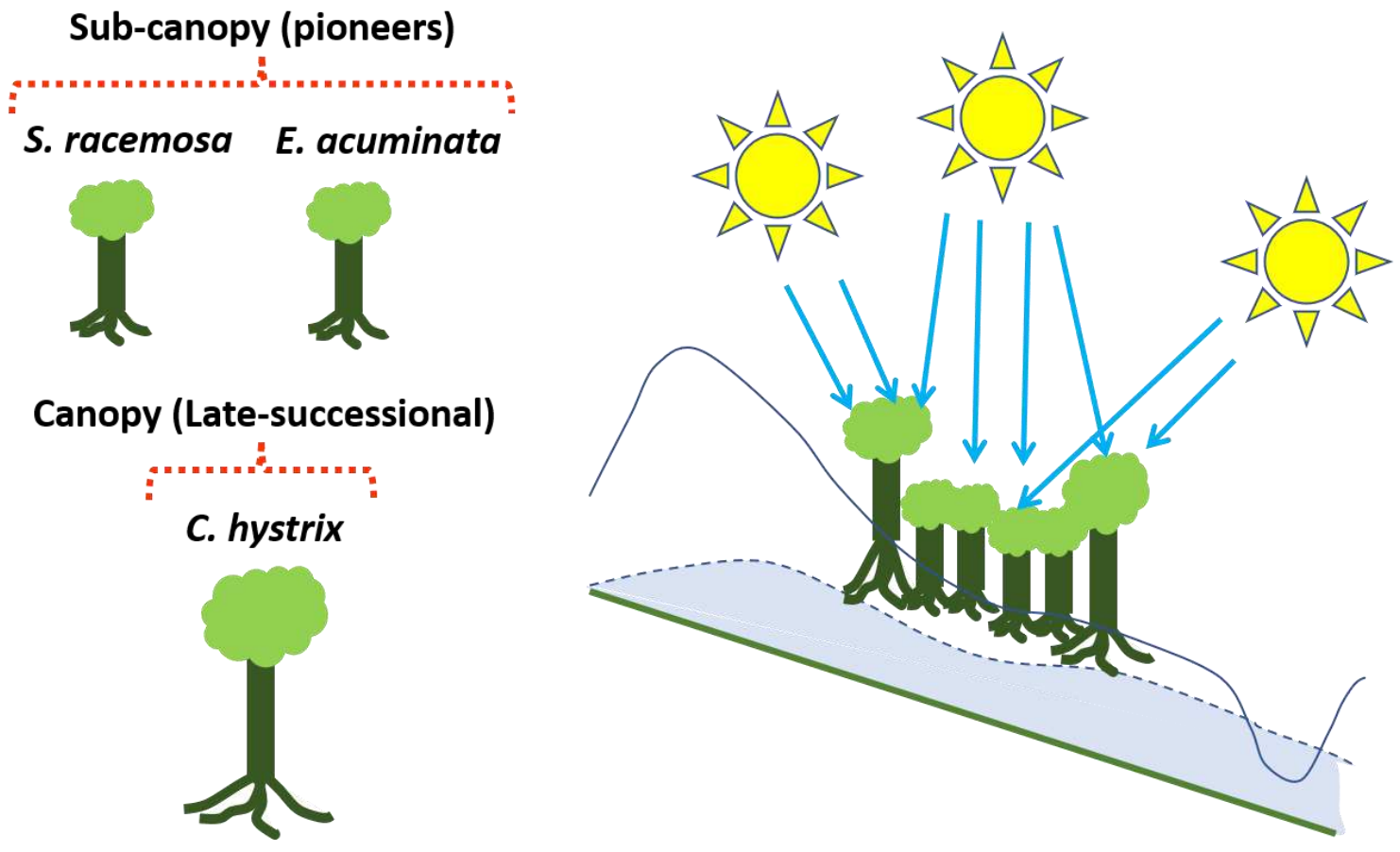

Figure 7. Pictorial representation of the interactive relationship between placement of pioneer and emergent in the forest canopy, diurnal shifts in sunlight availability and plant water-use in a typical sloped mountain environment in Himalaya. 


\section{Tables}

Table 1. Life-forms and ecophysiological characteristics of the three species used for sap flow measurements.

\begin{tabular}{|c|c|c|c|c|c|c|}
\hline Species & Family & Form & $\begin{array}{l}\text { Functional } \\
\text { group }\end{array}$ & $\begin{array}{l}\text { Canopy } \\
\text { position }\end{array}$ & $\begin{array}{l}\text { Rooting } \\
\text { depth }\end{array}$ & Wood type \\
\hline S. racemosa & Symplocaceae & $\begin{array}{l}\text { Small-medium } \\
\text { trees }\end{array}$ & Pioneers & In-canopy & Shallow & $\begin{array}{l}\text { Diffuse- } \\
\text { porous }\end{array}$ \\
\hline E. acuminata & Pentaphylacaceae & $\begin{array}{l}\text { Shrubs-small } \\
\text { trees }\end{array}$ & Pioneers & In-canopy & Shallow & $\begin{array}{l}\text { Diffuse- } \\
\text { porous }\end{array}$ \\
\hline C. hystrix & Fagaceae & Large trees & $\begin{array}{l}\text { Late- } \\
\text { successional }\end{array}$ & Emergent & Deep & $\begin{array}{l}\text { Semi ring- } \\
\text { porous }\end{array}$ \\
\hline
\end{tabular}


Table 2. Biometric details ( \pm standard deviation) of the three species instrumented for sap flow measurements along with the total number of data days and number of radial probes installed per species.

\begin{tabular}{lcccccc}
\hline Species & No. of trees & $\mathbf{D B H}(\mathbf{m})$ & $\begin{array}{c}\text { Basal area } \\
\left(\mathbf{m}^{2}\right)\end{array}$ & $\begin{array}{c}\text { Sapwood area } \\
\left(\mathbf{m}^{2}\right)\end{array}$ & $\begin{array}{c}\text { No. of radial } \\
\text { probes/tree }\end{array}$ & $\begin{array}{c}\text { Data } \\
(\mathbf{d a y s})\end{array}$ \\
\hline S. racemosa & 5 & $0.21 \pm 0.06$ & $0.036 \pm 0.02$ & $0.032 \pm 0.02$ & 5 & 49 \\
E. acuminata & 5 & $0.19 \pm 0.04$ & $0.028 \pm 0.01$ & $0.026 \pm 0.01$ & 4 & 87 \\
C. hystrix & 3 & $0.34 \pm 0.2$ & $0.11 \pm 0.12$ & $0.037 \pm 0.02$ & 5 & 99 \\
\hline
\end{tabular}


Table 3. Estimates of sap flux density (J), whole-tree sap flow (V), tree-to-tree coefficient of variation in sap flow (COV) in the studied species and at stand-level. Percentage biases in whole-tree sap flow (V)estimation due to ignoring radial and azimuthal variability (standard deviation in parentheses) are presented across species and in stand transpiration.

\begin{tabular}{|c|c|c|c|c|}
\hline Species & $\begin{array}{c}\mathrm{J} \\
\left(\mathrm{cm}^{3} \mathbf{c m}^{2} \mathbf{h r}^{-1}\right)\end{array}$ & $\begin{array}{c}\mathrm{V} \\
\left(\mathrm{kg} \mathrm{hr}^{-1}\right)\end{array}$ & $\begin{array}{c}\text { Radial bias } \\
(\%)\end{array}$ & $\begin{array}{c}\text { Azimuthal bias } \\
(\%)\end{array}$ \\
\hline S. racemosa & $28(2)$ & $26(11)$ & $8(4)$ & $-5(12)$ \\
\hline E. acuminata & $21(10)$ & $15(8)$ & $1(3)$ & $5(12)$ \\
\hline C. hystrix & $13(5)$ & $23(16)$ & $8(7)$ & $-21(41)$ \\
\hline Stand-level & $22(9)$ & $21(11)$ & $9(5)$ & $-16(24)$ \\
\hline
\end{tabular}


Table 4. Results from Generalized least squares (GLS) linear regression model with corARMA correlational structure for transpiration $(* P<0.05, * * P<0.01$, *** $P<0.001)$. Predictor variables include Incoming short-wave radiation $\left(\mathrm{R}_{\mathrm{s}}, \mathrm{kW} \mathrm{m}^{-2}\right)$, Vapour Pressure Deficit (VPD, $\left.\mathrm{kPa}\right)$, transpiration $\left(\mathrm{T}, \mathrm{mm} \mathrm{h}^{-1}\right)$ and soil moisture $\left(\mathrm{S}, \mathrm{mm} \mathrm{h}^{-1}\right)$.

\begin{tabular}{|c|c|c|c|c|c|c|c|}
\hline Season & $\begin{array}{l}\text { No. of } \\
\text { days }\end{array}$ & $\begin{array}{l}\text { Varia } \\
\text { bles }\end{array}$ & $\begin{array}{l}\text { Lag } \\
\text { (hours) }\end{array}$ & $\begin{array}{l}\text { Coefficie } \\
\text { nts }\end{array}$ & $\begin{array}{l}\text { Std. } \\
\text { Error }\end{array}$ & t-value & p-value $(P)$ \\
\hline \multirow{6}{*}{ Winter } & & $\mathrm{S}$ & 0 & -0.008 & 0.058 & -0.145 & 0.885 \\
\hline & 9 & $\mathrm{R}_{\mathrm{s}}$ & 2 & 0.187 & 0.079 & 2.366 & $0.019 *$ \\
\hline & & VPD & 1 & 0.182 & 0.197 & 0.919 & 0.359 \\
\hline & & $\mathrm{S}$ & 0 & 0.019 & 0.032 & 0.617 & 0.538 \\
\hline & 16 & $\mathrm{R}_{\mathrm{S}}$ & 0 & 0.119 & 0.021 & 5.574 & $<0.001 * * *$ \\
\hline & & VPD & 6 & -0.003 & 0.075 & -0.039 & 0.969 \\
\hline \multirow{3}{*}{ Summer } & & $\mathrm{S}$ & 0 & 0.004 & 0.006 & 0.688 & 0.492 \\
\hline & 24 & $\mathrm{R}_{\mathrm{s}}$ & 2 & 0.039 & 0.035 & 1.116 & 0.265 \\
\hline & & VPD & 2 & 0.223 & 0.066 & 3.401 & $<0.001 * * *$ \\
\hline
\end{tabular}




\section{Supplementary Files}

This is a list of supplementary files associated with this preprint. Click to download.

- SupplimentarytablesfiguresTSFMK.docx 